SPECIES VISITATION AT FREE-CHOICE QUAIL FEEDERS

IN WEST TEXAS

\author{
A Thesis \\ by \\ KELLY DIANE HENSON

\begin{abstract}
Submitted to the Office of Graduate Studies of
Texas A\&M University

in partial fulfillment of the requirements for the degree of

MASTER OF SCIENCE
\end{abstract}

May 2006

Major Subject: Wildlife and Fisheries Sciences 


\title{
SPECIES VISITATION AT FREE-CHOICE QUAIL FEEDERS \\ IN WEST TEXAS
}

\author{
A Thesis \\ by \\ KELLY DIANE HENSON

\begin{abstract}
Submitted to the Office of Graduate Studies of
Texas A\&M University

in partial fulfillment of the requirements for the degree of
\end{abstract}

\section{MASTER OF SCIENCE}

Approved by:

Co-Chairs of Committee, Dale Rollins

Tom L. Linton

Committee Member Kim E. Dooley

Head of Department, Delbert M. Gatlin III

May 2006

Major Subject: Wildlife and Fisheries Sciences 


\begin{abstract}
Species Visitation at Free-Choice Quail Feeders in West Texas.

(May 2006)

Kelly Diane Henson, B.A., Angelo State University

Co-Chairs of Advisory Committee: Dr. Dale Rollins

Dr. Thomas Linton
\end{abstract}

Providing supplemental feed is a popular management practice for quail (northern bobwhite Colinus virginianus and scaled quail Callipepla squamata ) in Texas. It is common knowledge that non-target species, e.g., raccoons (Procyon lotor), are frequent visitors at feeding stations intended for quail. However, empirical data are scarce on seasonal visitation rates at such feeders, either by quail or by non-target species. The ecological efficacy and economic efficiency of a feeding program for quail depends on several variables; perhaps the most important of these is how much of the feed is consumed by quail versus various non-target species. I monitored species visitation seasonally at free-choice quail feeders with motion-sensing cameras at 4 sites in West Texas (Coke, Fisher and Stonewall counties). Quail feeders were monitored using active-infrared sensing camera systems and passive-infrared video systems, to compare data obtained via these 2 surveillance techniques. I tested 2 research hypotheses: 1) that quail feeders are visited by a wide range of non-target 
species; and 2) active-infrared surveillance will yield a more precise estimate of species visitation than estimates derived from passive video surveillance. Major findings included documentation of approximately 14 mammalian and 18 avian species that were recorded in a total of 6,558 events. Data analysis yielded a chronology of feeding behavior by all visiting species. I found that species visitation at quail feeders varied according to season, with the greatest number of events occurring during the fall and the fewest during the winter. Feeder visitation also varied according to lunar phase, with the fewest events occurring during the new moon phase. I recorded the duration of each event monitored on videotape, a total of 29,235 minutes, and determined that feeder visitation by raccoons comprised $43.2 \%$ of all time spent at quail feeders across all species. Visitation by bobwhite and scaled quail comprised only $5.4 \%$ of time spent at quail feeders by all visiting species. This study confirmed the need for strategy implementation that minimizes non-target consumption of feed intended for quail. 


\section{DEDICATION}

I dedicate this thesis to my late father and my late grandfather, David F.

Kingston and Lewis M. Spraggins, respectively. I wish to especially thank my family and cheering section for their patience, enthusiasm and endless sense of humor throughout the duration of this study. Thank you to Babe Spraggins, Linda Kingston, my husband Clint and my brother David "Wolf” Kingston. Special thanks to my 6 sons, Roger, Christian, Rusty, Dusty, Josh and Skyler. I hope that I have set an excellent example for all of you. 


\section{ACKNOWLEDGEMENTS}

I thank Dr. Dale Rollins, Dr. Tom Linton and Dr. Kim Dooley for serving on my graduate committee and for supervising my study.

I recognize the faculty and staff at the Texas A\&M University Research and Extension Center in San Angelo for providing technical support, equipment and training for my cooperators. Thanks to Ken Cearley and Jason Brooks for help with data collection and to Ben Taylor for technical assistance in preparation of the thesis. Dr. Cody Scott at Angelo State University and Drs. Travis Whitney and Dan Waldron at the Texas A\&M Research and Extension

Center at San Angelo provided counsel on statistical analyses.

The study could not have been conducted if not for the assistance of various landowners and access to their ranches, namely the Aiken Ranch, Bond Ranch, Box P Ranch and Wildcat Mountain Ranch. Don Aiken, Matt Lindsey and Hollis Farris were instrumental in data collection and troubleshooting in the field. Rebel Royall provided logistical support for the Stonewall County site. I owe my deepest thanks to Dr. Rollins for his time, patience, troubleshooting and advice that he dedicated to this study. 


\section{TABLE OF CONTENTS}

\section{Page}

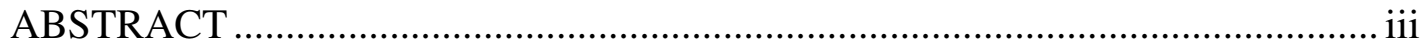

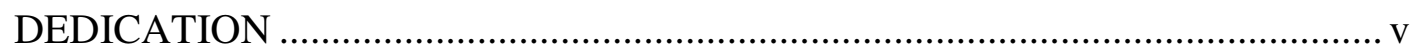

ACKNOWLEDGEMENTS ........................................................................ vi

TABLE OF CONTENTS ............................................................................. vii

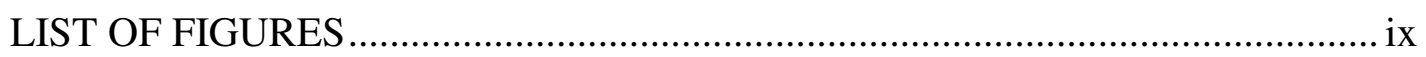

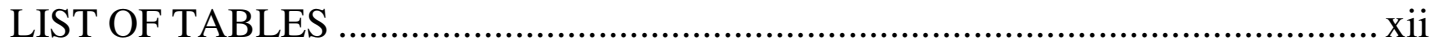

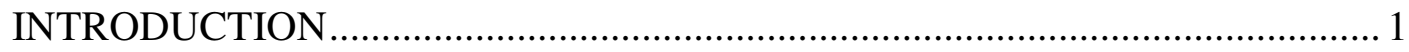

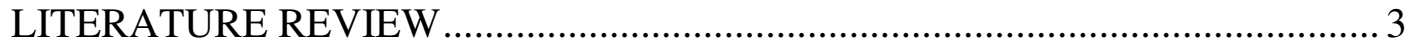

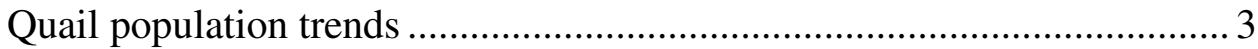

Supplemental feeding programs ......................................................... 4

Uses for motion-sensing camera systems in wildlife

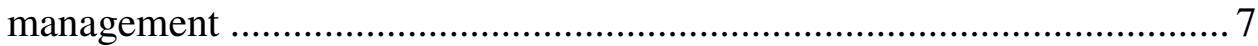

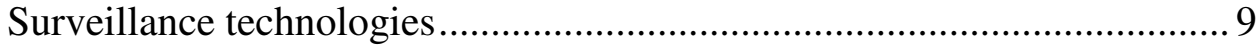

Methods of determining feed use by quail ........................................ 9

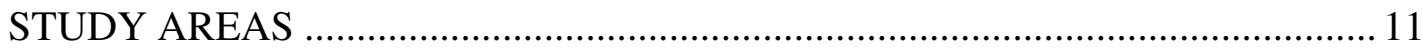

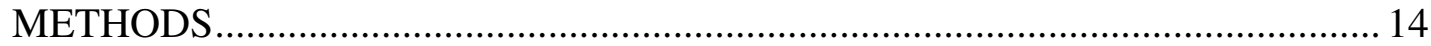

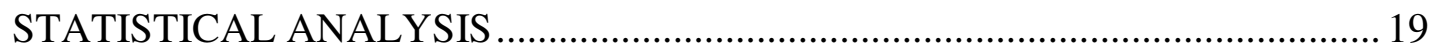

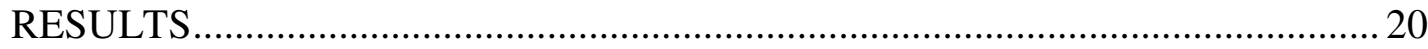

Feeder visitation ............................................................................ 20

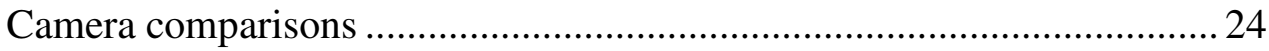

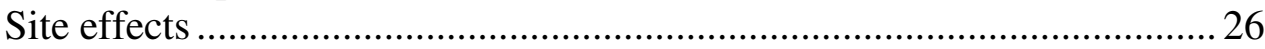

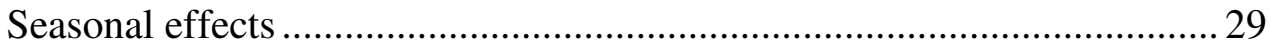

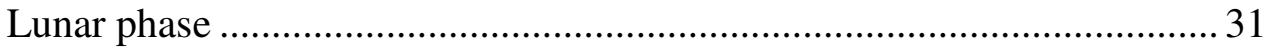

Duration of feeding ........................................................................ 31 


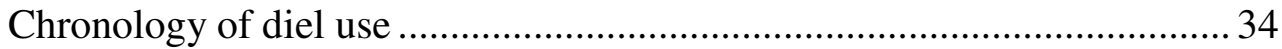

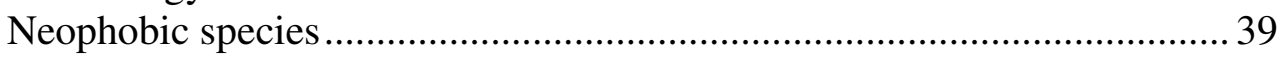

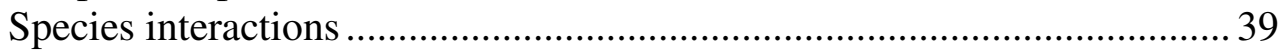

Evidence of predation at feeder sites.................................................. 41

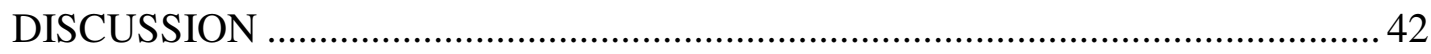

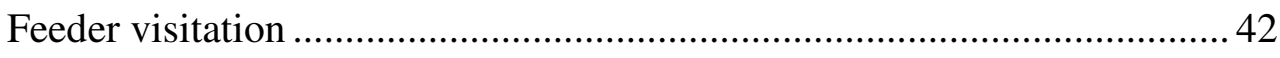

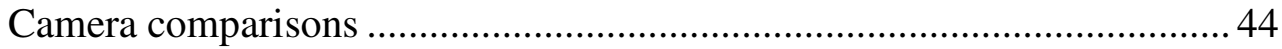

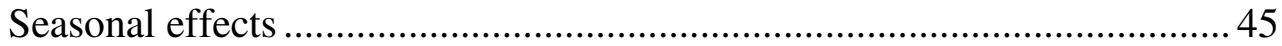

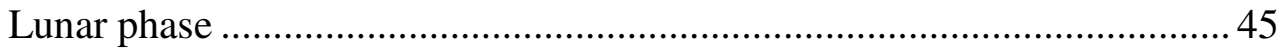

Duration of feeding events ........................................................... 46

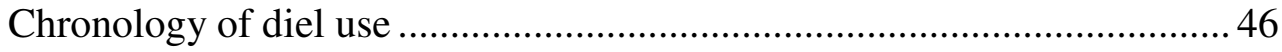

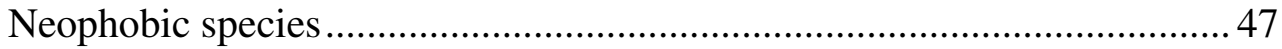

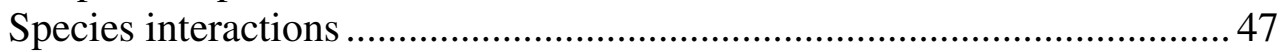

Evidence of predation at feeder sites................................................... 48

Special concerns relative to dove hunting ........................................... 48

CONCLUSIONS AND MANAGEMENT IMPLICATIONS ............................... 49

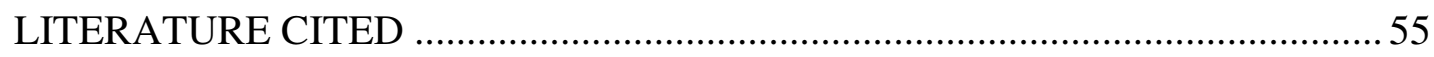

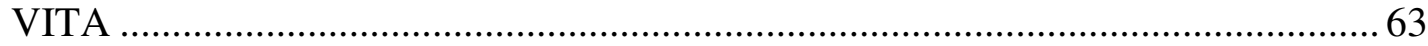




\section{LIST OF FIGURES}

Figure 1. Study sites for quail feeder surveillance study, fall 2002 - summer 2003. Counties included Coke (2 sites), Fisher and Stonewall

Figure 2. An example of the "Currie" quail feeder, as used at 3 of 4 sites during quail feeder surveillance study that took place from fall 2002-summer 2003, Texas

Figure 3. An example of an elevated galvanized box feeder, as used at Stonewall County site during quail feeder surveillance study, fall 2002-summer 2003, Texas....

Figure 4. Example of setup with both TrailMaster 1500 (background) and TrophyView surveillance systems monitoring a quail feeder in Coke County, Texas.

Figure 5. Relationships of photocapture rates between an active-infrared camera system (TrailMaster 1500) versus a passive-infrared video camera system (TrophyView) based on surveillance of free-choice quail feeders at 4 sites in West Texas, 2002-2003. Each point represents the percentage of total visitations for one of the 7 species categories.

Figure 6. Species visitation at free-choice quail feeders across all seasons as recorded by TrophyView camera system (left) TrailMaster system (right), Site 1, Coke County, Texas, Fall 2002 - Summer 2003.

Figure 7. Species visitation at free-choice quail feeders across all seasons as recorded by TrophyView camera system (left) TrailMaster system (right), Site 2, Coke County, Texas, Fall 2002 - Summer 2003. 
Figure 8. Species visitation at free-choice quail feeders across all seasons as recorded by TrophyView camera system (left) TrailMaster system (right), Site 3, Fisher County, Texas, Fall 2002 - Summer 2003

Figure 9. Species visitation at free-choice quail feeders across all seasons as recorded by TrophyView camera system (left) TrailMaster system (right), Site 4, Stonewall County, Texas, Fall 2002 - Summer 2003

Figure 10. Species visitation at free-choice quail feeders across all sites as recorded by season using (a) TrophyView camera system and (b) TrailMaster camera system, Texas, fall 2002 - summer 2003.

Figure 11. Chronograph of feeding behavior by quail at free-choice quail feeders in west Texas, fall 2002 - summer 2003

Figure 12. Chronograph of feeding behavior by wild turkey at free-choice quail feeders in west Texas, fall 2002 - summer 2003

Figure 13. Chronograph of feeding behavior by dove at free-choice quail feeders in west Texas, fall 2002 - summer 2003

Figure 14. Chronograph of feeding behavior by nongame birds at free-choice quail feeders in west Texas, fall 2002 - summer 2003

Figure 15. Chronograph of feeding behavior by raccoons at free-choice quail feeders in west Texas, fall 2002 - summer 2003 
Figure 16. Chronograph of feeding behavior by miscellaneous mammals at free-choice quail feeders in west Texas, fall 2002 - summer 2003.

Figure 17. Photograph of a nocturnal feeding event by bobwhite. Captured by TrailMaster 1500 system, Texas quail feeder surveillance study, fall 2002-summer 2003

Figure 18. Neophobic species photocaptured by Trail Master system included (from top left) badger, bobcat, and coyote, Texas quail feeder surveillance study, fall 2002-summer 2003

Figure 19. Raccoons were the most problematic non-target species encountered during a study of free-choice quail feeders in west Texas, fall 2002 - summer 2003 


\section{LIST OF TABLES}

Table 1. Descriptive statistics for species visitation at free-choice quail feeders as estimated by TrophyView and TrailMaster cameras at 4 sites in west Texas, fall 2002-summer 2003

Table 2. Species recorded at free-choice quail feeders with TrailMaster 1500 and TrophyView camera systems across 4 sites in west Texas, fall 2002 - summer 2003

Table 3. Species visitation by lunar phase at free-choice quail feeders as estimated by TrophyView camera system at 4 sites in west Texas, fall 2002 - summer 2003

Table 4. Time (minutes) spent at free-choice quail feeders as documented by TrophyView video cameras, fall 2002 - summer 2003 


\section{INTRODUCTION}

Providing supplemental feed is a popular management practice for quail (northern bobwhite Colinus virginianus and scaled quail Callipepla squamata) in Texas (Boyer 1989, DeMaso et al. 2002). Quail managers on private lands use feeding programs to sustain quail through food and weather emergencies, increase and maintain quail abundance and concentrate quail for easier hunting (Boyer 1989, Hernandez et al. 1997, DeMaso et al. 2002). The efficacy of one's feeding program depends on several variables, perhaps the most important of which is how much of the feed is consumed by quail versus various non-target species. It is a given that non-target species such as raccoons (Procyor lotor) are frequent visitors at feeding stations intended for quail. However, few empirical data are available on seasonal visitation rates at such feeders by quail or non-target species. I tested 2 research hypotheses: 1) that quail feeders are visited by a wide range of non-target species; and 2) activeinfrared surveillance yields a more precise estimate of species visitation than estimates derived from passive video surveillance.

This thesis follows the style of Wildlife Society Bulletin. 
There were three objectives of this study. The first objective was to determine diel and seasonal visitation rates by species at free-choice quail feeders. The second objective was to compare surveillance results obtained with active-infrared versus passive infrared technology and the third objective was to evaluate lunar effects on visitation rates at quail feeders. 


\section{LITERATURE REVIEW}

\section{Quail population trends}

Although characterized by irruptions, bobwhite populations in Texas have been declining for the past 40 - 100 years. Causal factors involved in this decline are not defined well, but likely include habitat fragmentation (Brennan 1991, Wilkins et al. 2003), land use changes and encroachment by the red imported fire ant (Solenopsis invicta) (Allen et al. 1995). Weather patterns, specifically precipitation, affect quail reproduction in Texas. Significant rainfall

following drought conditions triggers population irruptions in west Texas.

Rollins and Carroll (2001) speculated that changes in land use, management practices and predator communities interact to depress quail populations over much of the bobwhite's range. Rollins and Carroll (2001) also cited the increasing trend of supplemental feeding for white-tailed deer (Odocoileus virgininianus) as a possible contributing factor to the abundance of mesocarnivores (e.g., raccoons [Procyon lotor]). Cooper and Ginnett (2000) found that the placement of deer feeders near quail nesting sites increased nest depredation if ground cover was sparse. They concluded that the attraction of predators such as raccoons and striped skunks (Mephitis mephitis) to the feeding site would increase nest depredation indirectly. 
Brennan's (1991) prediction that bobwhites could approach extinction in the southeastern states by 2005 stimulated a flurry of activity from researchers, hunters, landowners and quail enthusiasts. Brennan (2002) drew attention to a curious paradox regarding bobwhite biology and management. Although research has yielded great volumes of data concerning an array of quail habitat needs and management protocols, very little of this research has been applied successfully. Economics was identified as a primary cause for this, as quail hunting has become so expensive that only those who are wealthy enough to afford to own, lease or manage larger tracts of land are able to maximize their land's habitat for quail. Brennan (2002) argued that quail management is perhaps the most expensive form of wildlife habitat management in the world. Past research has identified potentially successful management protocols; however, most are too expensive, labor intensive or are in direct contrast to what landowners want to do with their lands (Webb and Guthery 1982). Supplemental feeding programs

Feeding of quail is common throughout the bobwhite's range. Frye (1954) noted that feeders concentrated birds for easier hunting. An earlier study by Dill (1939) documented effects of supplemental feeding and shelter use on California quail (Callipepla californica).

Several studies have examined the effectiveness of supplemental feeding programs as a means of increasing survival or abundance of quail (Frye 1954, Peoples 1992, Townsend et al. 1999, DeMaso et al. 2002). The general 
consensus has been that increasing food through the use of feeders does not increase covey size or density (Doerr and Silvy 2002, DeMaso et al. 2002), although feeding has been credited with aiding birds during emergency food shortages in severe winters (Townsend et al. 1999).

Giuliano et al. (1996) determined that macronutrient deficiencies can lead to reproductive failures in quail, although neither northern bobwhites nor scaled quail increased food consumption in response to low dietary protein. Guthery (1997) argued that food abundance was not a satisfactory predictor of population density on a management area. A 5-year study (1991-1996) in western Oklahoma concluded that supplemental feeding during winter did not increase covey size or fall density of quail populations (DeMaso et al. 2002).

DeMaso et al. (2002) listed 4 assumptions that must be met in order for a supplemental feed program to be successful: 1) the native food supply, e.g., availability of insects is limiting quail numbers; 2) no other habitat parameter, i.e., nesting cover, brood-rearing cover, restricts the population from increasing when supplemental food is provided; 3) quail will utilize supplemental feed, and 4) the quail will be more fit in terms of higher survival, more productive or more adept at escaping predators, when the food supply is improved. Areas of concern regarding supplemental feeding of quail include concentration of quail near feeders, leading to a greater incidence of predation, and the possible spread of disease from various species of birds using feeders. 
Several studies have identified that a major problem with quail feeders is use by non-target species which accounted for $75-99 \%$ of feed loss in these studies (Campbell 1957, Guthery 1986:56). Haugen (1957) reported problems such as feed clogging and spoilage that reduced feeder performance. Optimization of feeder design has been addressed in recent publications and includes recommendations such as adjustable openings to control amounts and types of feed used, waterproofing to reduce spoilage, larger holding capacity and feed containment that does not allow birds to stand in feed (Lehmann 1984, Guthery 1986).

Another problem with the use of quail feeders is potential contamination of the feed with aflatoxins (Oberheu and Dabbert 2001). Perez et al. (2001) found that white-winged doves (Zenaida asiatica) and northern bobwhites did not avoid contaminated feed. Although the hazard of aflatoxocosis in quail has not been documented under field conditions, the risk may be considerable. Many studies (Wilson et al.1978, Stewart 1985, Moore 2004) found that the ingestion of aflatoxin-contaminated feed affected bobwhites adversely and increased morbidity and mortality of bobwhites in penned feeding trials. The amount of "deer corn" i.e., whole corn used to bait white-tailed deer in Texas exceeded 136,000 metric tons in 1998 (N. Wilkins, Texas Cooperative Extension, personal communication). 
Uses for motion-sensing camera systems in wildlife management

Motion-sensing camera systems can provide continuous surveillance of various wildlife- related activities of interest to managers. Martorello et al. (2001) used infrared-triggered camera systems for population studies of black bear (Ursus americanus). Langdon (2001) used automated cameras to monitor deer population density and movement. Koerth and Kroll (2000) used motionsensing cameras to determine preferred baits used to attract white-tailed deer. Alexy et al. (2001) used motion-activated video cameras to monitor scraping behavior in white-tailed deer. Taylor (2002) used video surveillance to document feed preference of white-tailed deer, feral hogs (Sus scrofa) and raccoons when given a choice of corn or whole cottonseed. Sweitzer et al. (2000) used automatic camera systems to monitor populations of feral swine in California. Foresman and Pearson (1998) found the remote camera method superior to track-plate methods of data collection for determining forest carnivores. Wolf et al. (2003) compared data obtained through camera surveillance to those obtained via track plates while monitoring bait use by raccoons. Moruzzi et al. (2002) used remote sensing cameras to survey carnivore distribution in Vermont.

Guthery et al. (2004) used video surveillance to monitor the incubation behavior of bobwhites. The use of camera and video surveillance in nest depredation studies has been a helpful tool in evaluating nest depredation. 


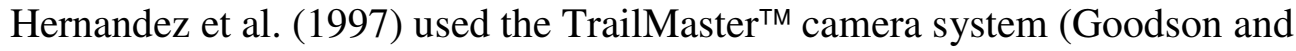
Associates, Lenexa, Kansas) to evaluate egg shell evidence as associated with various predators. Pietz and Granfors (2000) used video surveillance to study nest predation of grassland passerines. Hernandez et al. (1997) cautioned that use of surveillance equipment may be confounded by multiple species visiting a depredation event, or because of the wariness of certain neophobic species (e.g., coyotes, Canis latrans) and subsequent avoidance of the study area. York et al. (2001) documented that some targeted carnivore species avoided surveillance cameras.

Several studies (Savidge and Seibert 1988, Hernandez et al. 1997, Cooper and Ginnett 2000) have used motion-sensing cameras to monitor simulated quail nests. Fies and Puckett (2000) used remote cameras to monitor quail nests continually stocked with eggs from pen-raised quail. Jones et al. (2002) used motion-sensing cameras to monitor depredation of simulated nests. Staller (1995) and Guthery et al. (2004) used time-lapse video technology to monitor depredation of actual quail nests. Many of the arguments made against the reliability of determining nest depredation by evidence of destruction (Hernandez et al. 1997, Lariviere 1999) cite confounding of data due to interspecific overlap, intraspecific variation in depredation patterns, and depredation events involving multiple species. 


\section{Surveillance technologies}

One of the most popular camera systems for wildlife surveillance has been the TrailMaster camera system (Kucera and Barrett, http://www.trailmaster.com/index.php). As of 2005, it was the only commercially-available surveillance system that employed an active-infrared sensing system. An active-infrared sensing camera system consists of a transmitter, receiver and $35 \mathrm{~mm}$ camera. The infrared beam is focused across a specific area of traffic, in this case in front of a quail feeder. The camera is designed to record a photograph the instant the infrared beam is "interrupted"; the date and time are imprinted on the negative at the time of the photograph.

Most commercially-available camera systems employ passive-infrared sensing. Passive-infrared sensing technology systems are generally activated by simultaneously sensing motion and a difference in temperature. Passive infrared systems may employ $35 \mathrm{~mm}$ film, videotape, or more recently digital formats for recording images.

Methods of determining feed use by quail

Boyer (1989) monitored feeder use by quail by direct observation. He also noted any tracks found near the feeders as well. Doerr and Silvy (2002) determined feeder visitation by quail in south Texas by direct observation. Feeders were visited 5 times/month and the visual presence of bobwhites at (within $30 \mathrm{~m}$ of) feeders was assumed to be an indicator of feeder use by the birds. Boyer (1989) also described a 
pen study in which feeders were placed in large pens containing several non-target species as well as quail. He recorded the time spent at feeders by various species, as observed from a blind outside the enclosure. Raccoons were present in the pen, but their activities could not be recorded because of their nocturnal feeding behavior. Raccoons have been suspected as one of the greatest consumers of feed at quail feeders (D. Rollins, Texas Agricultural Experiment Station, San Angelo, personal communication).

The previous studies took place before the availability of motion-sensing cameras and infrared-sensing video equipment capable of recording nocturnal events. The amount of labor required for direct observation and possible disruption of feeding behavior by the presence of the observer limited our understanding of the use of feeders by quail. Technology exists that provides 24-hour surveillance of feeders with a minimal amount of human intrusion into the area. While infrared cameras have been used to remotely record wildlife activity since before 1970 (Cowardin and Ashe 1965 and Winkler and Adams 1968), this technology did not become popular with biologists until the development of commercially-available camera systems during the 1990s (Kucera and Barrett 1995) due to the technical skills required to integrate infrared illumination and camera equipment (Swann et al. 2004). 


\section{STUDY AREAS}

Private ranches located in Coke (2 sites), Fisher and Stonewall counties served as study areas (Fig. 1). Annual precipitation at the sites ranged from about 46.2 to $61 \mathrm{~cm}$, and winters ranged from basically snow-free (e.g., $7.6 \mathrm{~cm}$ annual snowfall at Coke County) to low snowfall potential (e.g., $12 \mathrm{~cm}$ annual snowfall at Stonewall County site). All sites were primarily rangeland dominated by mesquite (Prosopis glandulosa), prickly pear (Opuntia spp.), tobosa (Hilaria mutica), threeawns (Aristida spp.) and other midgrasses (e.g., Bothriochloa saccharoides). All sites had ongoing quail-feeding operations (most feeding milo only, from Oct - Mar). With the exception of the Stonewall County site, all sites used the "Currie" quail feeder (Fig. 2), a steel drum with 7-mm holes drilled near the bottom. The remaining site (Stonewall County) used an elevated metal bulk feeder (Fig. 3).

Bobwhites were common to abundant at all sites, while scaled quail were common on 1 site in Coke County (Wildcat Mountain Ranch) and rare at the Fisher County site. Wild turkeys (Meleagris gallopovo) were common at the 2 sites in Coke County but absent from the Fisher and Stonewall County sites. Coyotes (Canis latrans) were common at Fisher and Stonewall County sites but rare at the Coke County sites. 


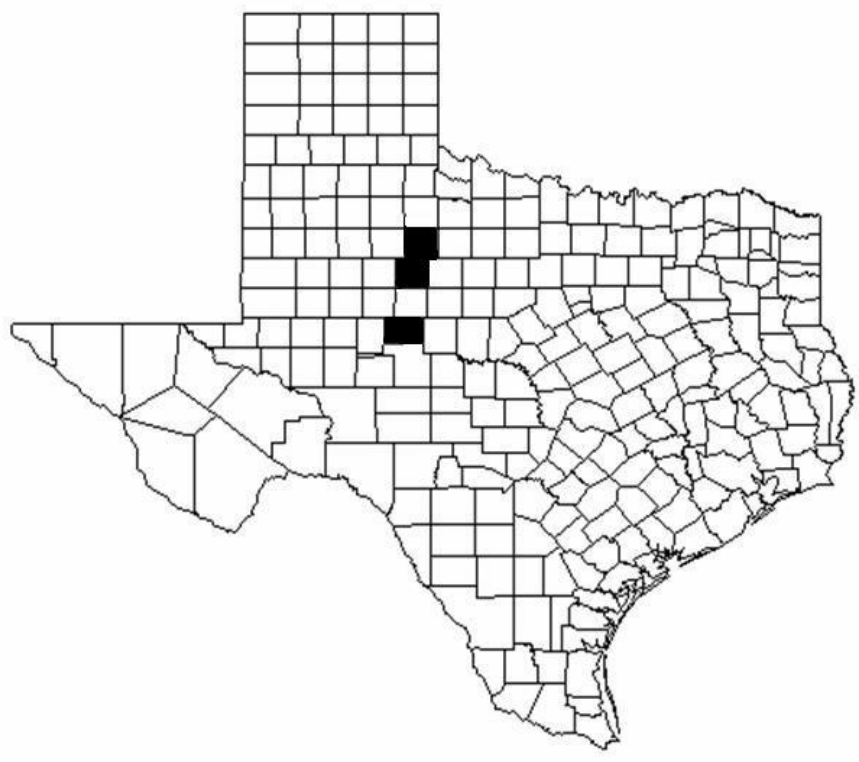

Figure 1. Study sites for quail feeder surveillance study, fall 2002 - summer 2003. Counties included Coke (2 sites), Fisher and Stonewall. 


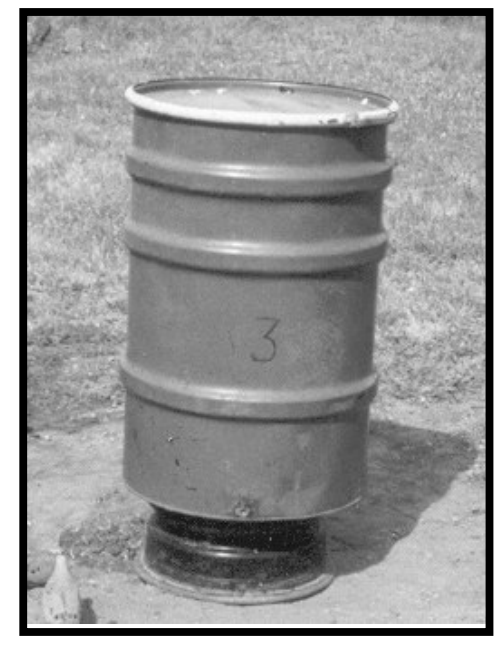

Figure 2. An example of the "Currie" quail feeder, as used at 3 of 4 sites during quail feeder surveillance study that took place from fall 2002-summer 2003, Texas.

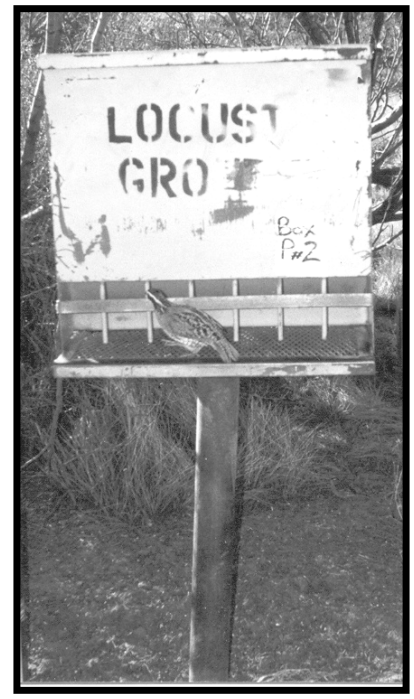

Figure 3. An example of an elevated galvanized box feeder, as used at Stonewall County site during quail feeder surveillance study, fall 2002summer 2003, Texas. 


\section{METHODS}

I monitored species visitation seasonally at free-choice quail feeders at 4 sites in West Texas ( 2 sites in Coke Co. and 1 site each in Fisher and Stonewall counties). I also documented feeding chronology and feeding behavior relative to lunar phase. I used active-infrared sensing camera systems (TrailMaster Model 1500 ${ }^{\mathrm{TM}}$ ) and passive-infrared sensing video systems (TrophyView ${ }^{\mathrm{TM}}$ video systems, Wildlife Surveillance Systems, Inc., Kerens, TX) in order to compare data obtained via these 2 surveillance techniques. At each of the 12 stations, feeders were monitored simultaneously with the TrailMaster and TrophyView systems.

The TrailMaster Model 1500 (TM) is an active-infrared system that uses $35 \mathrm{~mm}$ film as the recording medium. It provides 24-hour surveillance, but I programmed the system with a camera delay feature set at 30 minutes (i.e., successive photographs were taken at a minimum of 30 minute intervals) in an attempt to ensure independence between successive events. The transmitter and receiver were strapped to concrete blocks and the infrared beam was positioned to extend across the entrance holes to each feeder (Fig. 4). Feeder ports on the back side of the feeder (i.e., facing away from the cameras) were covered with duct tape to ensure that all species would feed on the side of the feeder monitored by cameras. 


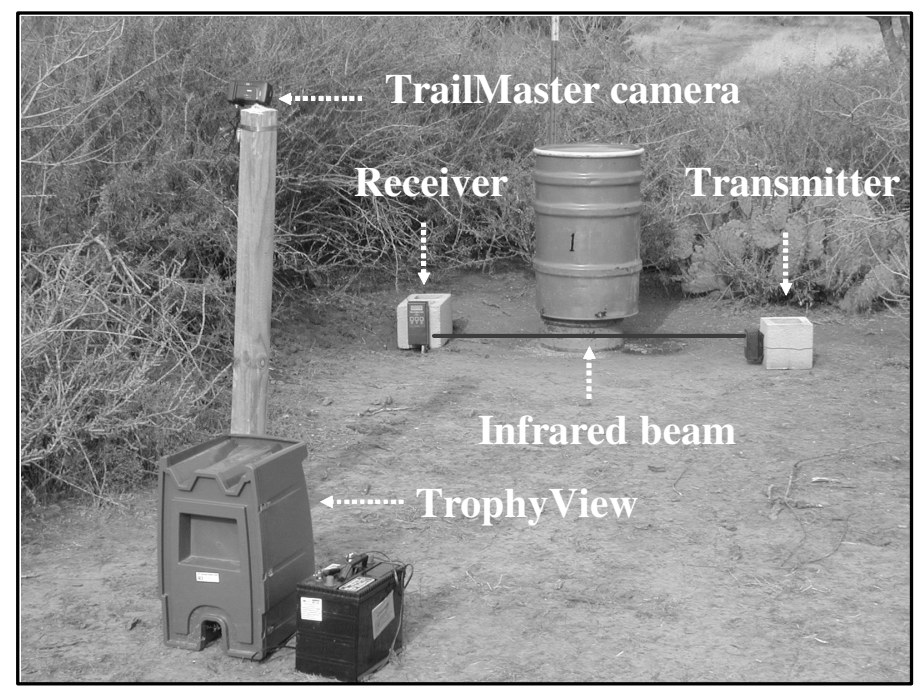

Figure 4. Example of setup with both TrailMaster 1500 (background) and TrophyView surveillance systems monitoring a quail feeder in Coke County, Texas. 
The $35 \mathrm{~mm}$ camera was placed on a post and aimed toward the feeder. The flash system for the camera was set to "fill-in" to provide a flash for all photographs.

The TrophyView (TV) video system is a passive system that provides 24hour video surveillance. The recorder is activated by either movement or by a heat source (i.e., animal) within the field of reception. The TV unit has about a 5 -second time lag between activation and when recording commences; recording continues for 30 seconds or until the visitor leaves the area. Infrared illumination permits non-intrusive surveillance.

Feeders were monitored during 4 time periods during 2002-2003: winter (Dec. 15 - Jan. 15), spring (Mar. 20 - Apr. 20), summer (June 15 - July 15) and fall (Aug. 15 - Sep. 15). A total of 3 feeders (separated by $>1 \mathrm{~km}$ ) were monitored at each site. Each feeder was monitored until $>60$ photographs had been obtained. Animals at feeder sites were given 1 week to become accustomed to surveillance equipment before data collection began. Video surveillance was conducted concurrently for the length of time it took to acquire the required number of photographs.

I defined a feeder event as a photograph or segment of videotape recorded at the point that the respective camera system was activated. Upon inspection of the photographs or video, I scored each event into 1 of the following categories: false event (in which no observable species appeared), quail, 
nongame bird, mourning dove, wild turkey, raccoon or miscellaneous mammal. I defined nongame birds as all avian species except for quail (bobwhite and scaled), mourning doves, and wild turkey. I defined miscellaneous mammals as all mammals except for raccoons.

Variables recorded included the site, season, feeder number, lunar phase, time of the visitation and the duration of the event (TV data only). I assigned each species a measure of relative abundance based on their photo-capture rates: Absent (no observations), Rare ( $<3$ observations), Uncommon (1-5\% of visitations), Common (6-20\% of visitations), or Abundant ( $>20 \%$ of visitations). These designations are indicative of species that were recorded during the course of this study and not necessarily the general populations within the study sites. Feeders and cameras were monitored approximately every other day to replace film and videotapes. Observers were asked to monitor immediate surroundings of the feeder for evidence (i.e., scattered feathers) of any predation events that might have occurred. Predation events were classified only according to the prey species involved (e.g., mourning dove); no attempts were made to distinguish between avian and mammalian predators responsible for any kills.

The TV video system records the time, date, and lunar phase on the videotape. Hence I created a chronology of feeding events based on the time stamp on the videotape for each event and categorized events relative to lunar phase. I used video recordings to document behavioral interactions between 
species, as preliminary footage revealed that when certain non-target species (e.g., red-winged blackbirds, Agelaius phoeniceus; mourning doves, wild turkeys) were present at quail feeders, quail avoided the feeder. 


\section{STATISTICAL ANALYSIS}

Visitation rates by species were computed seasonally and expressed as percent of total number of events as recorded by that camera system. I compared visitation rates as estimated by the TM camera unit to video recorded by the TV system by comparing frequencies of photocaptures among the various species. I computed means and standard errors (SE) in order to calculate 95\% confidence intervals. I used Spearman's rank correlation coefficient to evaluate the relationship between camera types. I used nonparametric tests for 2 reasons: (1) observations were assumed to be nonindependent of one another (especially in the case of the continuous surveillance provided by the TV camera), and (2) data were discrete (i.e., presence/absence). Significant differences $(\alpha=0.05)$ were inferred if confidence intervals were non-overlapping. 


\section{RESULTS}

I recorded a total of 6,558 events; 5,055 using the TV system and 1,503 with the TM system (Table 1). Species documented (but not their visitation rates, see below) at feeders were essentially identical with the exception of coyotes. I documented 1 instance where a coyote was photo-captured by the TM system but was missed by the TV system.

\section{Feeder visitation}

I recorded approximately (i.e., identification to species was not always possible for similar taxa, e.g., sparrows or rodents) 14 mammalian and 18 avian species during the course of this study (Table 2). The most common species observed across all sites and seasons was raccoons, accounting for 42.7 and $49.3 \%$ of visitors as estimated by TV and TM cameras, respectively (Table 1). Nongame birds were recorded in 32.5 (TV) and 50.2\% (TM) of events. Quail accounted for only 7.3 (TV) $-11.3 \%$ (TM) of visitors. Mourning doves comprised 15.6 and $22.3 \%$ of visitations, respectively, while wild turkeys accounted for 6.5 and $9.1 \%$, respectively. Miscellaneous mammal visitations (which typically consisted of white-tailed deer, eastern cottontails (Sylvilagus floridanus) and ground squirrels (Spermophilus sp.) comprised 12.0 and $8.6 \%$ of visitations, respectively. Apparently false events accounted for 5.9 and $8.7 \%$ between TV and TM cameras, respectively. 
Table 1. Descriptive statistics for species visitation at free-choice quail feeders as estimated by TrophyView and TrailMaster cameras at 4 sites in west Texas, fall 2002-summer 2003.

TrophyView

\begin{tabular}{|c|c|c|c|c|c|c|c|c|}
\hline Species & $\mathrm{N}$ & $\%$ & SE & $\begin{array}{c}95 \% \text { CI } \\
(\min , \max )\end{array}$ & $\mathrm{N}$ & $\%$ & SE & $\begin{array}{c}95 \% \text { CI } \\
(\min , \max )\end{array}$ \\
\hline Quail & 290 & 7.3 & 0.4 & $6.5<\bar{x}<8.1$ & 98 & 11.3 & 1.1 & $9.1<\bar{x}<13.5$ \\
\hline Nongame bird & 1,277 & 32.5 & 0.8 & $\begin{array}{c}30.9<\bar{x}< \\
34.1\end{array}$ & 439 & 50.2 & 1.7 & $46.8<\bar{x}<53.6$ \\
\hline Mourning dove & 621 & 15.6 & 0.6 & $\begin{array}{c}14.4<\bar{x}< \\
16.8\end{array}$ & 195 & 22.3 & 1.4 & $18.1<\bar{x}<26.5$ \\
\hline Wild turkey & 259 & 6.5 & 0.4 & $5.7<\bar{x}<7.4$ & 80 & 9.1 & 1.0 & $7.1<\bar{x}<11.1$ \\
\hline Raccoon & 1,700 & 42.7 & 0.8 & $\begin{array}{c}41.1<\bar{x}< \\
44\end{array}$ & 432 & 49.3 & 1.7 & $44.2<\bar{x}<54.4$ \\
\hline Misc. mammal $^{l}$ & 607 & 12.0 & 0.3 & $\begin{array}{c}11.8<\bar{x}< \\
12.6\end{array}$ & 129 & 8.6 & 0.3 & $8.0<\bar{x}<9.2$ \\
\hline False event ${ }^{2}$ & 301 & 5.9 & 0.4 & $5.1<\bar{x}<6.7$ & 130 & 8.7 & 0.3 & $8.1<\bar{x}<9.3$ \\
\hline Total & 5,055 & $122.5^{3}$ & & & 1,503 & 159.5 & & \\
\hline
\end{tabular}

${ }^{l}$ Includes eastern cottontail, white-tailed deer, rodents (Neotoma, Peromyscus, Spermophilus), opossum, striped skunk, nine-banded armadillo, porcupine, badger, bobcat, coyote, feral hog, feral cat, and cows.

${ }^{2}$ Camera system was triggered but no species was observed.

${ }^{3}$ Rows do not add to $100 \%$ because multiple species were recorded in some events 
Table 2. Species recorded at free-choice quail feeders with TrailMaster 1500 and TrophyView camera systems across 4 sites in west Texas, fall 2002 - summer 2003.

\begin{tabular}{|c|c|c|c|}
\hline Common name & Scientific name & \multicolumn{2}{|c|}{$\begin{array}{c}\text { Relative abundance as gauged } \\
\text { by }\end{array}$} \\
\hline Mammals & & TrailMaster $^{1}$ & TrophyView \\
\hline Nine-banded armadillo & (Dasypus novemcinctus) & Uncommon & Uncommon \\
\hline Badger & (Taxidea taxus) & Rare & Rare \\
\hline Bobcat & (Lynx rufus) & Rare & Rare \\
\hline Cottontail rabbit & (Sylvilagus floridanus) & Abundant & Abundant \\
\hline Coyote & (Canis latrans) & Rare & Absent \\
\hline Domestic cat & (Felis domesticus) & Rare & Rare \\
\hline Ground squirrel & (Spermophilus sp.) & Abundant & Abundant \\
\hline Mice & (Peromyscus sp.) & Abundant & Abundant \\
\hline Opossum & (Didelphis virginiana) & Rare & Uncommon \\
\hline Porcupine & (Erethizon dorsatum) & Rare & Rare \\
\hline Raccoon & (Procyon lotor) & Abundant & Abundant \\
\hline Rats & (Neotoma, Sigmodon) & Uncommon & Uncommon \\
\hline Striped skunk & (Mephitis mephitis) & Rare & Uncommon \\
\hline White-tailed deer & (Odocoileus virginianus) & Abundant & Abundant \\
\hline
\end{tabular}

\footnotetext{
${ }^{1}$ Absent (not observed), Rare ( $<3$ observations), Uncommon (1 - 5\% of visitations), Common (6 -20\% of visitations), Abundant (> 20\% of visitations)
} 
Table 2. (continued)

\begin{tabular}{|c|c|c|c|}
\hline \multirow[t]{2}{*}{ Common name } & \multirow[t]{2}{*}{ Scientific name } & \multicolumn{2}{|c|}{$\begin{array}{l}\text { Relative abundance as gauged } \\
\text { by }\end{array}$} \\
\hline & & TrailMaster $^{2}$ & TrophyView \\
\hline \multicolumn{4}{|l|}{ Birds } \\
\hline Blue jay & (Cyanocitta cristata) & Rare & Uncommon \\
\hline Brown towhee & (Pipilo fuscus) & Uncommon & Uncommon \\
\hline Brown-headed cowbird & (Molothrus ater) & Uncommon & Uncommon \\
\hline Cactus wren & (Campylorhynchus brunneicapillus) & Common & Common \\
\hline Golden-fronted & (Melanerpes aurifrons) & Common & Common \\
\hline \multicolumn{4}{|l|}{ woodpecker } \\
\hline Greater roadrunner & (Geococcyx californianus) & Rare & Uncommon \\
\hline Meadowlark & (Sturnella spp.) & Abundant & Abundant \\
\hline Mourning dove & (Zenaida macroura) & Abundant & Abundant \\
\hline Northern bobwhite & (Colinus virginianus) & Common & Common \\
\hline Northern cardinal & (Cardinalis cardinalis) & Abundant & Abundant \\
\hline Northern flicker & (Colaptes auratus) & Common & Common \\
\hline Northern mockingbird & (Mimus polyglottos) & Uncommon & Uncommon \\
\hline Red-winged blackbird & (Agelaius phoeniceus) & Abundant & Abundant \\
\hline Scaled quail & (Callipepla squamata & Uncommon & Abundant \\
\hline Sparrows & (Spizella sp.) & Abundant & Abundant \\
\hline White-winged dove & (Zenaida asiatica) & Uncommon & Uncommon \\
\hline Wild turkey & (Meleagris gallopavo) & Common & Common \\
\hline
\end{tabular}

\footnotetext{
${ }^{2}$ Absent (0 observations), Rare ( $<3$ observations), Uncommon (1 - 5\% of visitations), Common (6 -20\% of visitations), Abundant ( $>20 \%$ of visitations)
} 


\section{Camera comparisons}

Species visitation as assessed by the TV system recorded approximately 3 times the number of events as compared to the TM system. The TM camera system and the TV video surveillance system were correlated (Spearman's correlation coefficient, $r=0.75,6 \mathrm{df}, P=0.05$ ) (Fig. 5). Species visitations across all species were estimated similarly between camera types (Table 1; Friedman's test; $Q=1.27,1 \mathrm{df} ; P=0.26$ ). However, individual species visitation rates had non-overlapping confidence intervals for all species except wild turkeys and possibly raccoons. The greatest magnitude of difference between surveillance systems was noted for nongame birds (TV $=32.5 \%$ vs. $\mathrm{TM}=50.2 \%)$. False events had overlapping confidence intervals.

Raccoons and miscellaneous mammals tended to be underestimated by the TrailMaster surveillance system. As these species were for the most part nocturnal, I deduce that my setting of the TrailMaster to be activated after 30 minute intervals led to the majority of my photography data being obtained during the daylight hours. Had I set the interval at 1 hour or more between collections of events I might have attained a more representative cross section of species visitation. False events, in which no visible species appeared, tended to be lower 


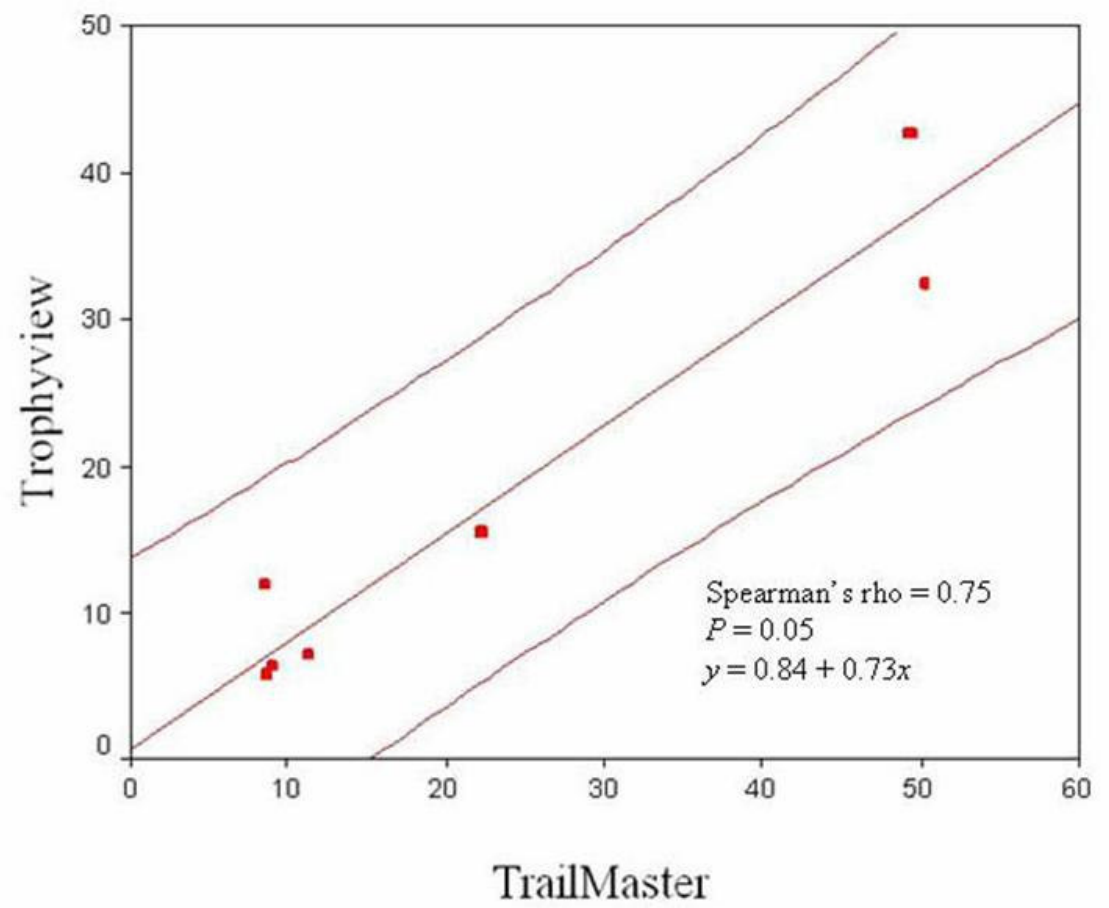

Figure 5. Relationships of photocapture rates between an activeinfrared camera system (TrailMaster 1500) versus a passive-infrared video camera system (TrophyView) based on surveillance of freechoice quail feeders at 4 sites in West Texas, 2002-2003. Each point represents the percentage of total visitations for one of the 7 species categories. 
in the data obtained via the TrophyView system (5.9\% of events as opposed to $8.7 \%$ as measured by the TrailMaster). These false events could be attributed to neophobic species vacating the area at onset of recording, wind or high temperatures triggering the equipment, as most false events occurred in relatively high wind conditions between the hours of 1100 and 1400 . The TrophyView system, set to record at 30 second intervals as long as either movement or a change in ambient temperature were detected, recorded approximately 3 times the number of events as the TrailMaster system $(5,055$ events as opposed to 1,503 events). This difference could have saturated the data, leading to an under-representation of the percentage of false events. With the exception of the categories of raccoons and miscellaneous mammals, the data obtained via the two surveillance systems were correlated.

Site effects

Visitations by quail ranged from $4 \%$ of total visitations at Stonewall County to $9 \%$ at Fisher County, as measured by the TrophyView system (Figs. 6-9). Nongame birds and raccoons were the most frequent visitors across all sites, accounting for $20 \%$ (Coke County site 2) to $44 \%$ (Stonewall County) for nongame bird ranges, and 22\% (Stonewall County) to $43 \%$ (Coke County site 2), for ranges of raccoon visitation. Visitations by wild turkeys 


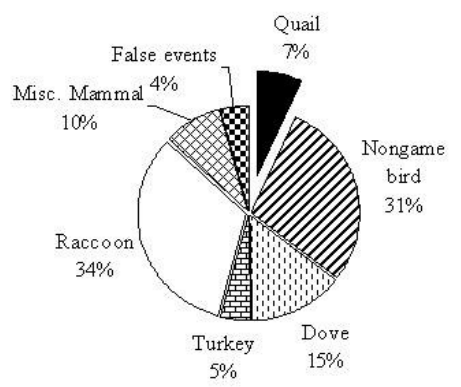

TrophyView $n=1,254$ events

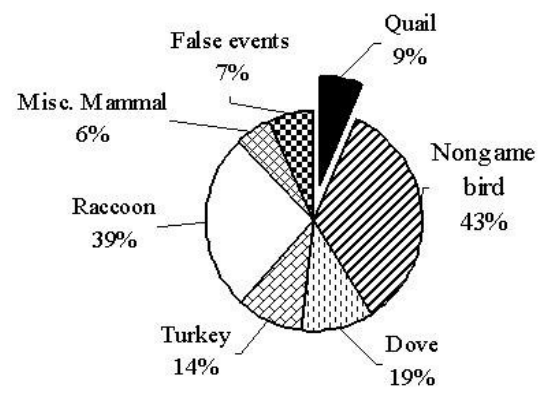

TrailMaster $n=382$ events

Figure 6. Species visitation at free-choice quail feeders across all seasons as recorded by TrophyView system (left) TrailMaster system (right), Site 1, Coke County, Texas, Fall 2002-Summer 2003.

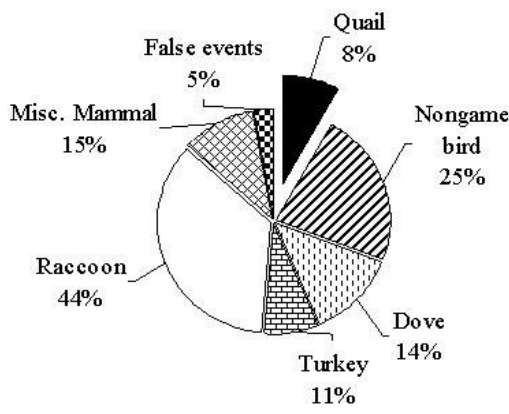

TrophyView $n=1,254$ events

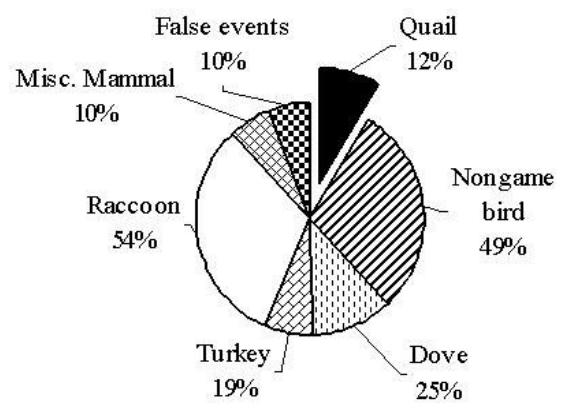

TrailMaster $n=382$ events

Figure 7. Species visitation at free-choice quail feeders across all seasons as recorded by TrophyView system (left) TrailMaster system (right), Site 2, Coke County, Texas, Fall 2002-Summer 2003. 


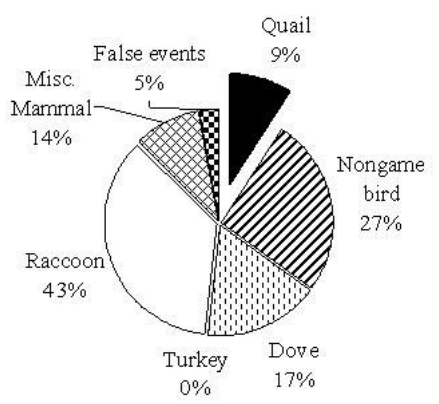

TrophyView $n=1,254$ events

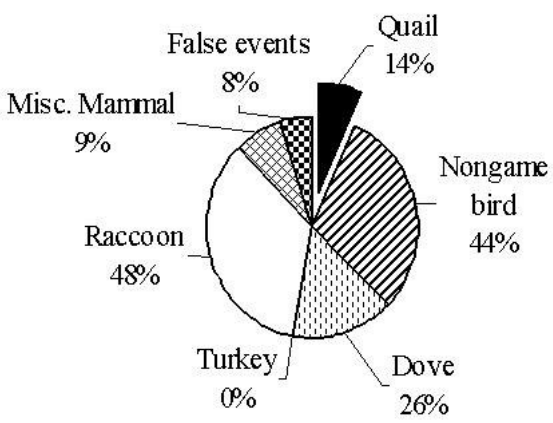

TrailMaster $n=382$ events

Figure 8. Species visitation at free-choice quail feeders across all seasons as recorded by TrophyView system (left) TrailMaster system (right), Site 3, Fisher County, Texas, Fall 2002-Summer 2003.

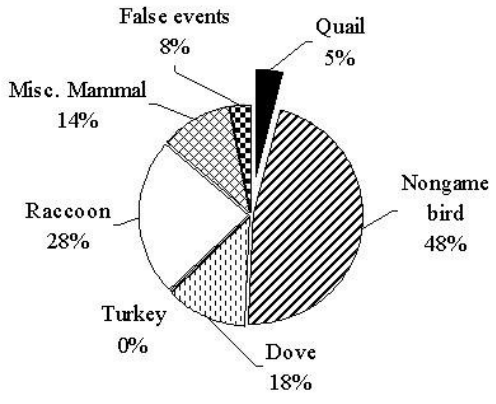

TrophyView $n=1,254$ events

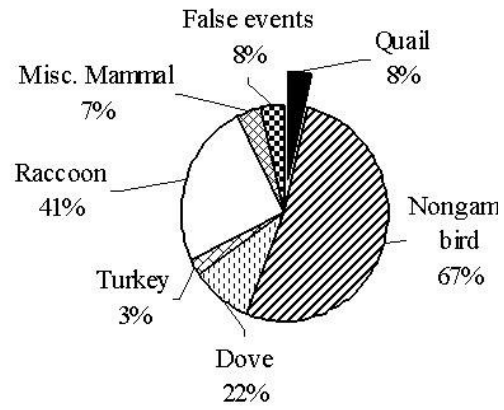

TrailMaster $n=382$ events

Figure 9. Species visitation at free-choice quail feeders across all seasons as recorded by TrophyView system (left) TrailMaster system (right), Site 4, Stonewall County, Texas, Fall 2002-Summer 2003. 
ranged from 0 (Stonewall and Fisher Counties) to 5\% (Coke County sites 1 and 2). Visitation by dove ranged from $14 \%$ (Coke County site 1) to $16 \%$ (Stonewall County). Miscellaneous mammals were documented as ranging from $11 \%$ of total visitation (Coke County site 1) to 15\% (Coke County site 2).

Seasonal effects

Species visitation varied across seasons (Fig. 10). Quail visitation across all sites was greatest during winter (8\%) and least during summer (3\%). Nongame birds (mostly neotropical migrants) accounted for $64 \%$ of all visitations during the winter but comprised only $4 \%$ of visitations during fall. Mourning doves frequented feeders most during spring (28\%) but were relatively scarce during fall (5\%). Visitation by raccoons showed the greatest variation across seasons, ranging from $6 \%$ (winter) to $63 \%$ (fall). Visitation by miscellaneous mammals ranged from 7\% (spring and winter) to $22 \%$ (fall). Wild turkey visitation ranged from $0 \%$ in the winter and fall seasons, to $18 \%$ in the spring season. Greatest numbers of events across species were recorded during the fall season (1544 events, TrophyView) and the least number of events across species were recorded during the winter season (1067 events, TrophyView). 
(a)

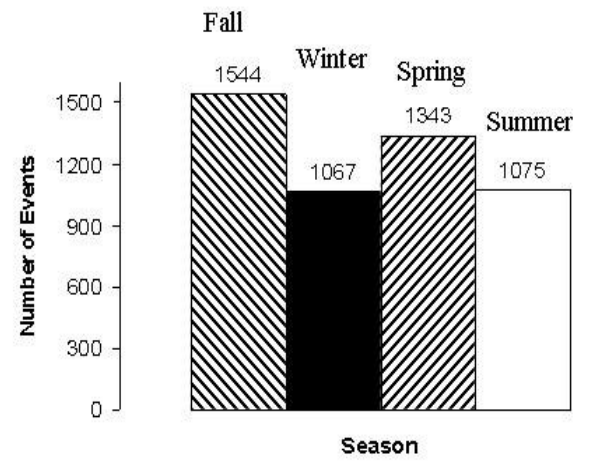

(b)

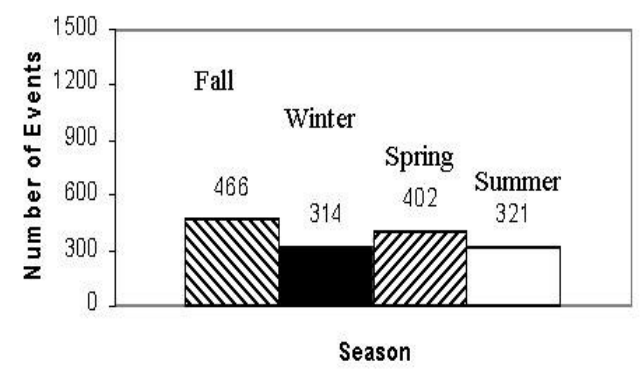

Figure 10. Species visitation at free-choice quail feeders across all sites as recorded by season using (a) TrophyView camera system and (b) TrailMaster camera system, Texas, fall 2002-summer 2003. 


\section{Lunar phase}

Feeder visitation across all species and sites varied by lunar phase (Table 3). Visitation at feeders was lowest during the new moon ( $n=406$ events) and greatest during the last quarter ( $n=1,284$ events). Feeder visitation rates during full moon ( $n$ $=1,161$ events $)$ and first quarter $(n=1,124$ events $)$ were similar.

\section{Duration of feeding}

Surveillance with the TV system permitted me to measure duration of events (Table 4). There was wide variation in the duration of events across species. This measurement of event duration did not reflect feed consumption, but provided a representation of the amounts of time spent at the feeders by various species. Wild turkeys and quail were documented as having the least number of minutes of event duration (1,563 and1,576 respectively). Raccoons occupied most of the time spent at feeders (43.2\% of total event time across all sites). 
Table 3. Species visitation by lunar phase at free-choice quail feeders as estimated by TrophyView camera system at 4 sites in west Texas, fall 2002summer 2003.

Lunar phase

New Moon

First Quarter

Full Moon

Last Quarter

1,551

4,824

Total
$\%$

10.4

28.2

29.1

0.5

32.1

0.5

0.9

0.5
$95 \%$ CI

(min, max)

$8.6<\bar{x}<12.2$

$27.2<\bar{x}<29.2$

$28.1<\bar{x}<30.1$

$31.1<\bar{x}<33.1$

100.0 
Table 4. Time (minutes) spent at free-choice quail feeders as documented by TrophyView video cameras, fall 2002-summer 2003.

\begin{tabular}{|c|c|c|c|c|c|c|}
\hline Species & Fall & Winter & Spring & Summer & Total & Percent of \\
& & & & & & \\
total & \\
\hline Quail & 566 & 604 & 360 & 46 & 1,576 & 16.6 \\
\hline Nongame birds & 188 & 2,772 & 1,423 & 472 & 4,855 & 11.6 \\
\hline Dove & 191 & 636 & 1,644 & 237 & 3,392 & 5.3 \\
\hline Turkey & 68 & 0 & 1,124 & 80 & 1,563 & 43.2 \\
\hline Raccoon & 7,352 & 31 & 1,172 & 1,469 & 12,620 & 17.9 \\
\hline Miscellaneous & 3,016 & 505 & 428 & 376 & 5,229 & \\
\hline mammals & & & & & & 29,235 \\
\hline
\end{tabular}




\section{Chronology of diel use}

With a few exceptions, use of quail feeders by various birds was limited to diurnal periods (generally with bimodal peaks of feeding activity, in morning and late afternoon) while mammals (especially raccoons) dominated nocturnal periods (Figs. 11-16). Greatest use of feeders by quail occurred between 0600-0900 and 1500-2100 hours. Non-game birds visited feeders equally across all daylight hours. Raccoons used feeders almost exclusively between the hours of 1800-0900. Miscellaneous mammals were present at the feeders at all times during surveillance, with the greatest numbers of events occurring between the hours of 2100 and 0000 . Diurnal use of feeders by mammals generally consisted of visitations by cottontails and ground squirrels, with cottontails more common during crepuscular times.

I recorded 3 instances of nocturnal feeding by quail. Two instances involving scaled quail occurred just prior to dawn and the other (Fig. 17) involved bobwhite and occurred at 0300 . This event was less than 1 minute in duration and occurred during the last quarter lunar phase. The TV surveillance system captured all 3 events but the TM surveillance system captured only the event containing the scaled quail. 
a. Quail

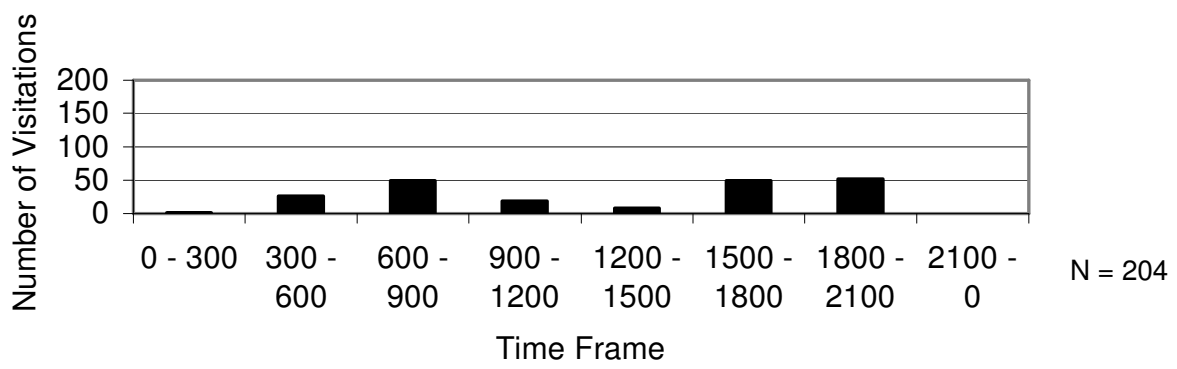

Figure 11. Chronograph of feeder visitation by quail at free-choice quail feeders in west Texas, fall 2002 - summer 2003.

b. Wild turkey

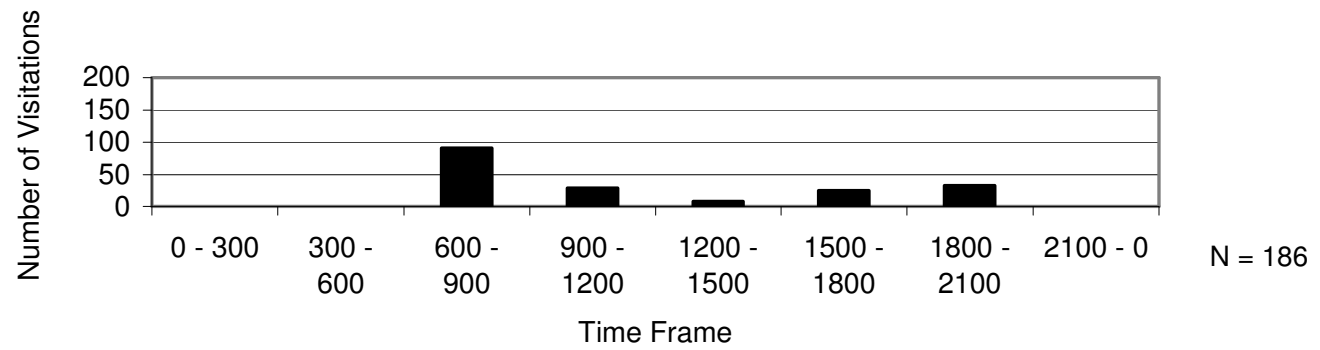

Figure 12. Chronograph of feeder visitation by wild turkey at free-choice quail feeders in west Texas, fall 2002 - summer 2003. 
a. Dove

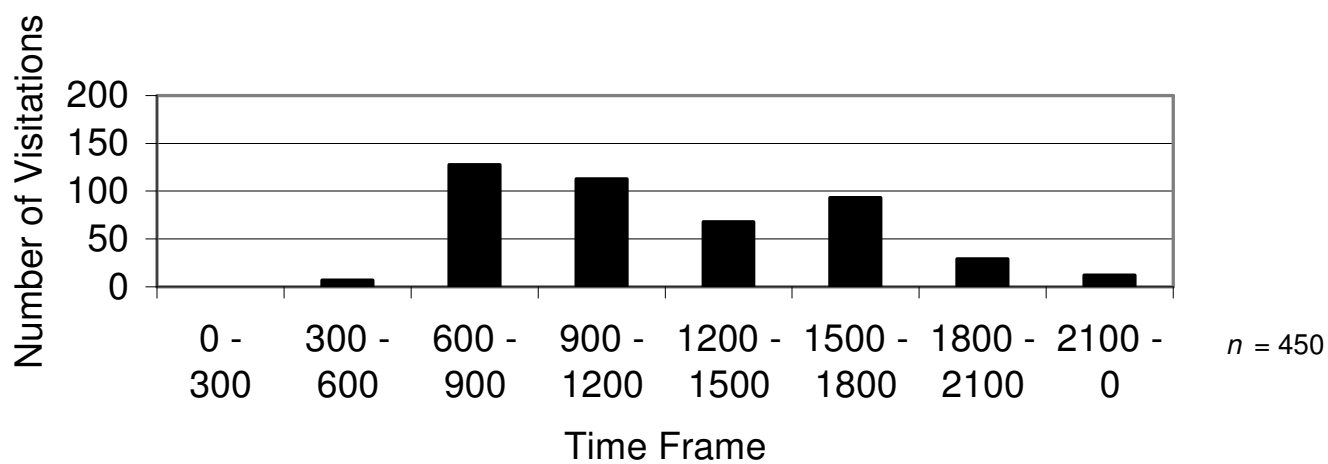

Figure 13. Chronograph of feeder visitation by dove at free-choice quail feeders in west Texas, fall 2002 - summer 2003.

b. Nongame birds

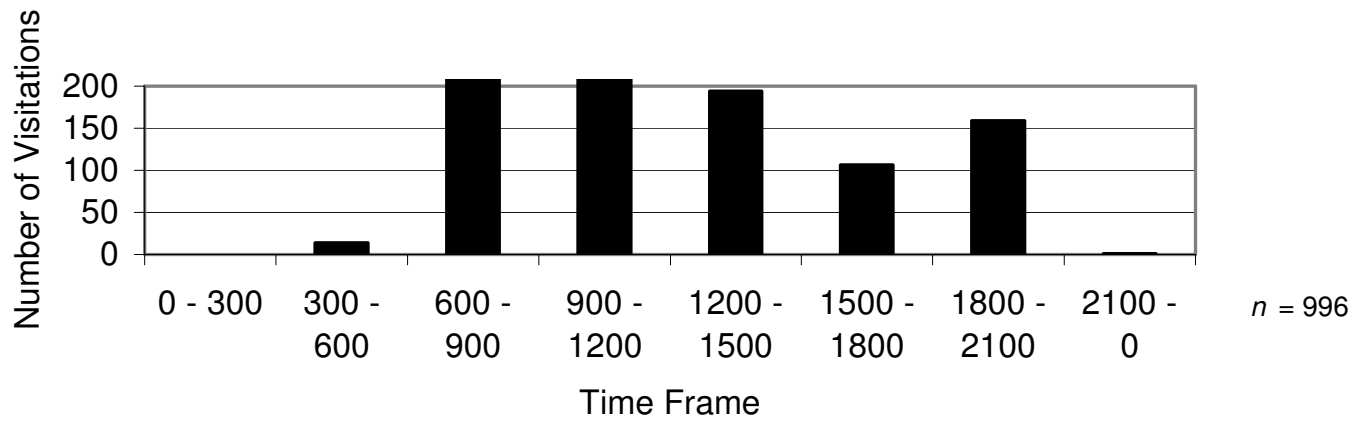

Figure 14. Chronograph of feeder visitation by nongame birds at free-choice quail feeders in west Texas, fall 2002 - summer 2003. 
a. Raccoons

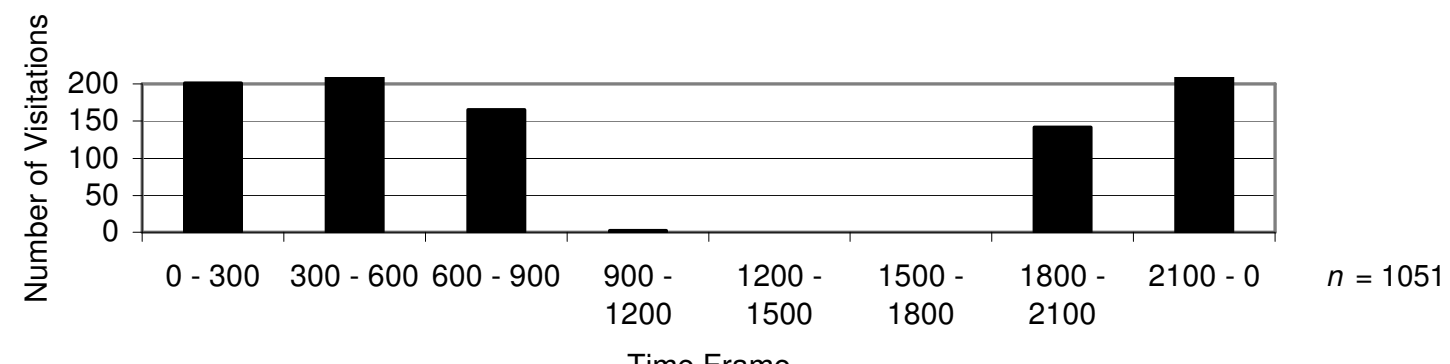

Figure 15. Chronograph of feeder visitation by raccoons at free-choice quail feeders in west Texas, fall 2002 - summer 2003.

b. Misc. Mammals

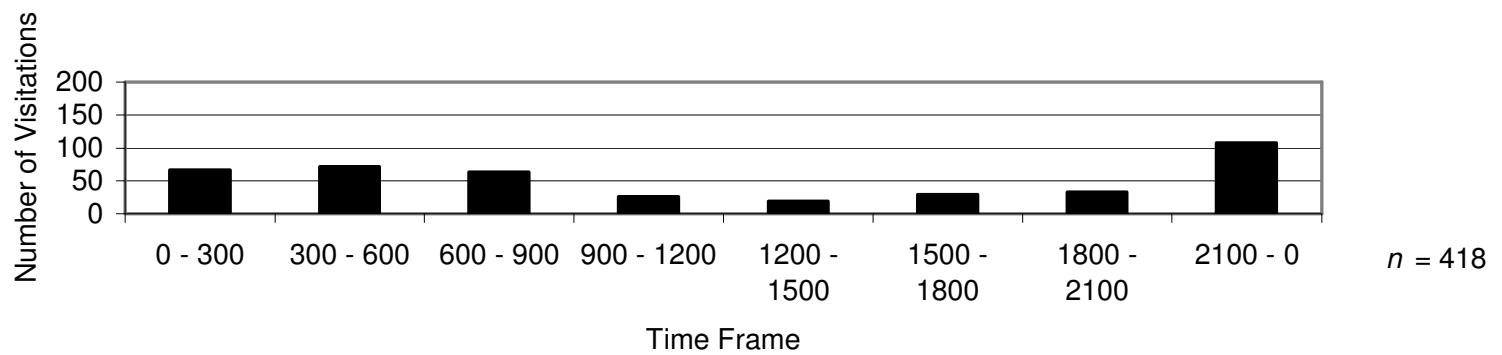

Figure 16. Chronograph of feeder visitation by miscellaneous mammals at free-choice quail feeders in west Texas, fall 2002 - summer 2003. 


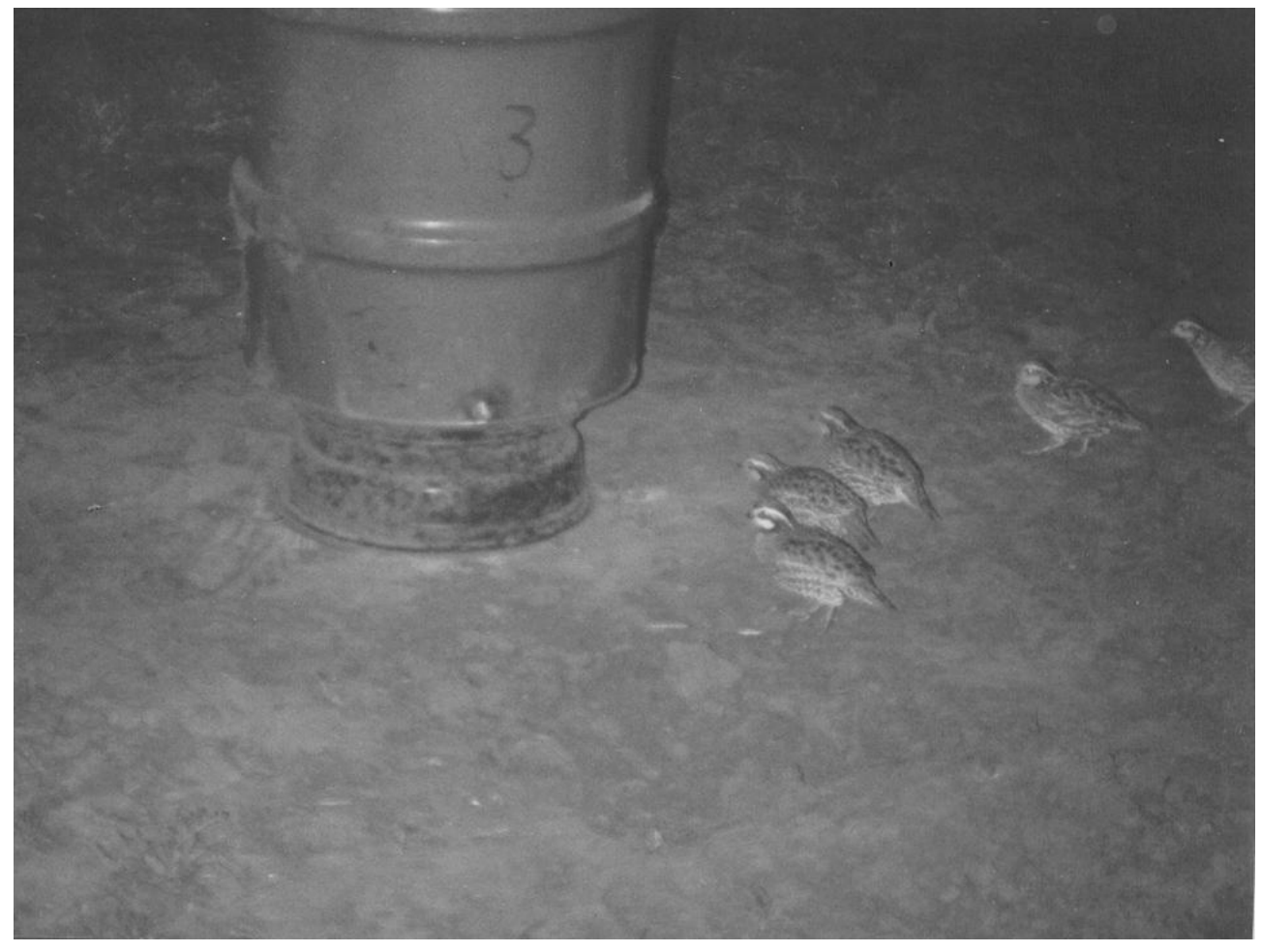

Figure 17. Photograph of a nocturnal feeding event by bobwhite. Captured by TrailMaster 1500 system, Texas quail feeder surveillance study, fall 2002-summer 2003. 


\section{Neophobic species}

I documented 4 instances (Coke County site 2, Stonewall County) where neophobic species ( 1 coyote, 2 bobcats, 1 badger) were photo-captured by the TM system but missed by the TV system (Fig. 18). A period of 3-5 seconds

eclipses between the time the animal was detected (i.e., the video recorder was activated) and videotaping actually began. However, I measured no difference of false events recorded by the 2 camera systems (Table 1). Species interactions

I documented a few instances $(<5)$ of non-game birds chasing quail away from the feeders. Quail would mingle and feed with dove and a few species of non-game birds (e.g., various sparrows); however, they vacated the area at the appearance of meadowlarks, red-winged blackbirds, golden-fronted woodpeckers, and wild turkey. 


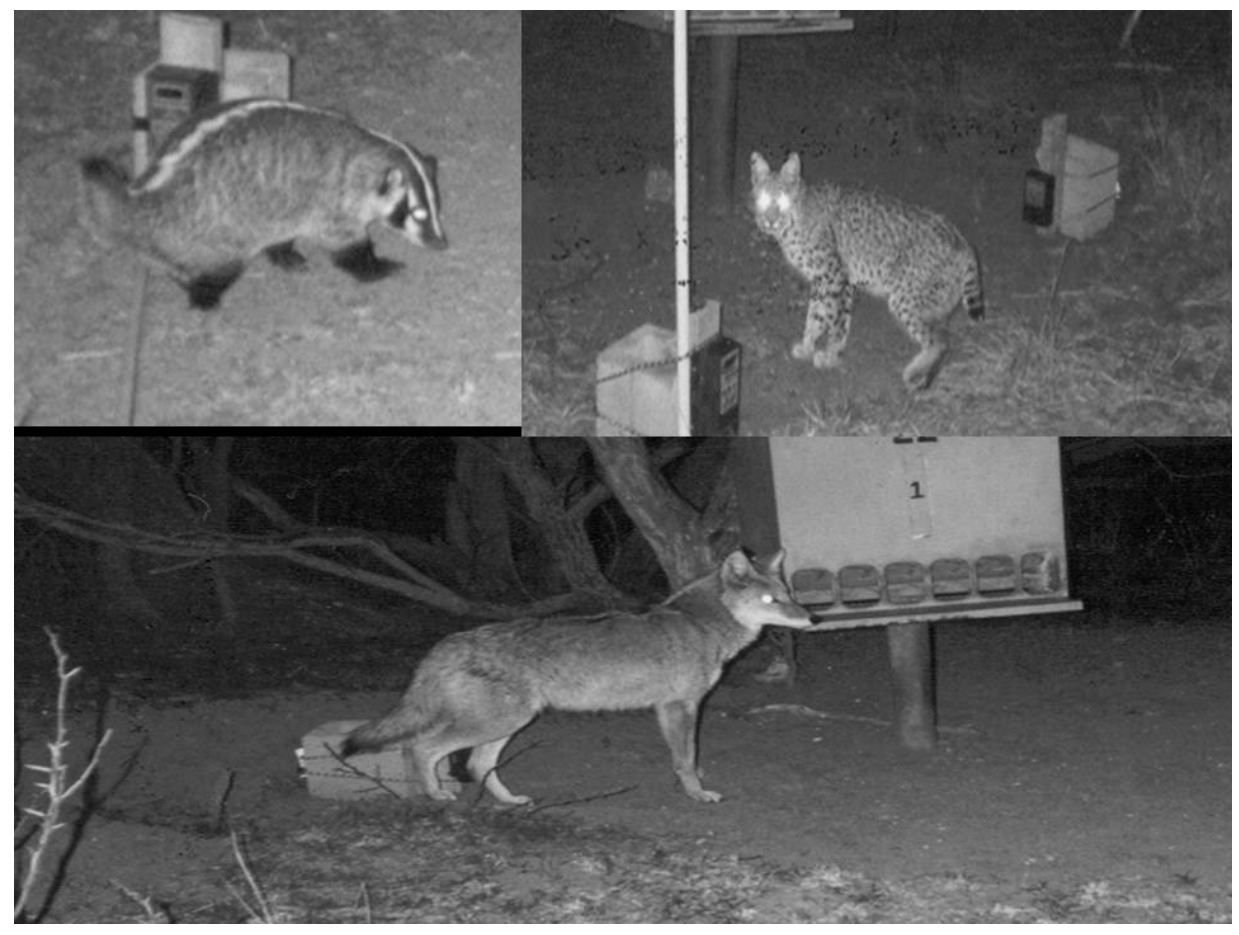

Figure 18. Neophobic species photocaptured by Trail Master system included (from top left) badger, bobcat, and coyote, Texas quail feeder surveillance study, fall 2002-summer 2003. 
Coveys of scaled quail did not mingle with coveys of northern bobwhites; events always consisted of 1 species of quail or the other. Raccoons were observed using the feeders concurrently with deer and rodents, although there were frequent intraspecific displays of aggression among raccoons. Interspecific aggression was observed between raccoons and deer and also between nongame birds and quail.

\section{Evidence of predation at feeder sites}

Potential predators of quail recorded at feeders included bobcats, feral cats, coyotes, gray foxes (Urocyon cineroeargenteus), striped skunks, raccoons, opossums and roadrunners. Observers reported only 1 instance of predation on quail (a bobwhite at the Fisher County site) at or near feeders. However, 15 instances of predation on mourning doves were reported across the 4 sites. Given that such predation on doves was presumably limited to daylight hours, raptors and not mesomammals were likely responsible. 


\section{DISCUSSION}

\section{Feeder visitation}

Because of the investment of time and capital required for a supplemental feeding program, landowners should be concerned about the use of quail feeders by non-target species. Estimates of feed disappearance were collected for 1 site (Coke County site 1) and averaged $1.64 \mathrm{~kg}$ day. Based on these levels of disappearance, it cost $\$ 15$ per feeder per week. Feed disappearance by species is impossible to quantify, but I speculate that visitation rates and time spent feeding are correlates of feed loss. Assuming a priori that visitation rates equate to feed consumption, raccoons consumed $\$ 7.50$ of each $\$ 15$ spent per feeder, with quail averaging only $\$ 0.75$ of each $\$ 15$ (average of TM and TV data). Time spent feeding as suggested by Trophyview cameras also confirmed the preponderance of raccoons at feeders; these data showed raccoons comprised $43.2 \%$ of the total time during feeding events recorded. I speculate that these levels of feed loss to raccoons are actually conservative. The modus operandi of raccoons at the Currie quail feeders used at 3 of my study sites, as gauged by video surveillance, involves licking the feeder port and catching the milo in one of its paws. Relative to the modus operandi for quail, i.e., pecking a single kernel at a time, I surmise that the intake rate of milo relative to the time spent feeding is greater for raccoons than any of the other species groups monitored. 
Accordingly, raccoons may account for perhaps $60-75 \%$ of the feed disappearance; they are surely the major non-target species for the quail manager where they are abundant. Previous studies have shown that quail consumed $<25$ percent of the feed offered (Frye 1954, Campbell 1957, Haugen 1957, Guthery 1986, Kane 1988). Kozicky (1996) made the observation that it would be a mistake to claim that any feeder is raccoon-, cattle- or feral hog"proof". While cattle and feral hogs could be (mostly) excluded by incorporating suitable exclosures (e.g., hog panels), raccoons would be more difficult to exclude. Even if raccoons could be excluded, any exclosures would need to have large enough openings to accommodate quail, and likewise not function to "trap" any quail at a feeder by hindering a timely escape route.

Another potential serious competitor at feeders is feral swine. No feral hogs were photocaptured during the course of this study. Feral hogs were not known to occur at either site in Coke County, or in Fisher County but feral hogs were known to be common at the Stonewall County site. The Stonewall County site used an elevated feeder, so it is possible that events containing feral hogs were recorded as false events due to the elevated angles of the camera.

Only a single coyote was photocaptured (Stonewall County), although distribution of coyotes in Texas is described as statewide.

\section{Camera comparisons}

Data collected by the 2 surveillance systems were similar. One implication is the use of photography to create an accurate depiction of not only which 
species are using quail feeders, but also an indication of the amount of time they are spending at the feeder. Grounds for future study involve computing a bite to feed-consumption ratio, which could allow for refinement of the correlation between duration of event and feed consumption. If a significant positive correlation exists between these 2 variables, feed consumption could be reasonably estimated using TrailMaster photography.

Another implication is the cost of equipment: a video surveillance system at the time of this study averaged $\$ 1,100$; whereas, a $35 \mathrm{~mm}$ photography system cost less than half this amount. Ease of use and maintenance time were factors in comparing surveillance technologies; fewer problems were encountered with the TrophyView system during this study. Digital cameras have become the prevalent technology for monitoring feeders since the course of this study. Future studies are needed to ensure that feeder visitation rates obtained via digital cameras (which employ a passive-infrared sensing technology) are correlated with estimates I obtained with active-infrared (TM) and passiveinfrared video (TV) technologies. Digital cameras may be more effective in photocapturing neophobic species like coyotes due to their comparative lack of noise (i.e., as a result of camera shutter a motor drive for advancing film) .

\section{Seasonal effects}

Feeder visitation by all species was greatest during the fall season.

Visitations by wild turkeys and raccoons diminished drastically $(0 \%$ and $6 \%$ of all visitations, respectively) from fall to winter. Some reduction may be 
attributed to the availability of corn in deer feeders, which is more prevalent in the winter months to accommodate deer hunting season. Turkeys and raccoons may have been attracted to the relative ease of use of deer feeders, i.e., picking up feed that had been dropped onto the ground from a "sling" feeder as opposed to digging milo out of the quail feeders. Greater numbers of events containing wild turkey during spring might be attributed to female dispersal. Spring is the time period of greatest dispersal movement by wild turkeys. Quail visitation at feeders was greatest during the fall and winter and least during summer as recorded by the TV surveillance system. If feeder visitation by quail is influenced by seasonal energy needs, then this pattern seems logical.

\section{Lunar phase}

The new moon phase consistently had lower visitation rates. This decrease in feeder activity during the new moon phase is consistent with behaviors observed across a broad range of species. Utschick (2003) reported low activities of riverine birds during the new moon phase during a yearlong study on lunar effects on diurnal bird activities. Keitt et al. (2004) found that moon phase was responsible for $96 \%$ of the variation in activity in a study of lunar effects on black-vented shearwaters (Puffinus opisthomelas), but they observed the least amount of activity occurring during the full moon phase. Palmer (1987) reported more boreal owl (Aegolius funereus) calling during a full moon than during any other moon phase. Kroll and Koerth (1996) found that white-tailed deer activity was greatest during the full moon phase. 


\section{Duration of feeding events}

Quail were observed feeding for $>2$ minutes at a time, then circling out of the surveillance area and returning to feed. Raccoon feeding bouts were commonly observed lasting for 2 hours or more. It is important to note that not all time spent at feeders by species involved actual feeding. Roadrunners, armadillos, skunks and badgers were observed walking through the surveillance areas without feeding or interacting with species present at the feeders. Raccoons, cows and rats inspected camera equipment on a regular basis. One bobcat sat down beside a feeder and remained there for $>15$ minutes. Raccoon behaviors included tampering with camera equipment, climbing on the feeders, sleeping beside the feeders, frolicking of kits, and dominance displays within feeding groups. Large flocks of nongame birds regularly congregated at feeders but spent the majority of their time circling the area, interacting with other birds, scratching in the dirt, taking dirt baths and preening. Feeding was observed, but I surmise that feed loss to nongame birds is not as substantial as their visitation rates would suggest.

\section{Chronology of diel use}

Visitations at free-choice quail feeders occurred at all hours of the day, but patterns were observed for various classes of animals. Avian species were essentially diurnal (with a few instances of nocturnal feeding by quail recorded) and mammalian visitors were mostly nocturnal. Greatest use of feeders by quail occurred between 0600 to 0900 and 1500 to 2100 hours. Land managers may 
develop strategies for diminishing use of feeders by non-target species if they are aware of what particular species are visiting feeders at specific time periods. In order to maximize feed consumption, a timed feeding system which makes feed available only during the morning and late-afternoon would likely be most beneficial to quail. The estimated cost of feeding raccoons may result in decisions to install timing mechanisms on quail feeders or lead to further research on diminishing use of quail feeders by raccoons.

\section{Neophobic species}

Quail, nongame birds, dove and wild turkey did not exhibit neophobic behavior as compared to mammalian visitors; i.e., startled reaction when photographed or leaving the area at the onset of a video recording. Deer and cottontail rabbits exhibited the most startled responses, either freezing for $<1$ minute or bolting from the surveillance area. Raccoons were observed ceasing feeding or other behaviors at the first camera flash, occasionally inspecting equipment, but then showed no response at subsequent camera flashes.

\section{Species interaction}

Nongame birds chased quail away from feeders on $>5$ occasions. Quail would mingle and feed with dove and sparrows but vacated the surveillance area at the appearance of meadowlarks, red-winged blackbirds, golden-fronted woodpeckers and wild turkeys. Scaled quail and northern bobwhites visited quail feeders asynchronously. Raccoons were observed exhibiting aggressive behavior within feeding groups and also toward approaching deer. Cottontails 
were observed feeding in the presence of other species, although mammal events involving skunks, armadillos, badgers or bobcats were sole events. Although quail were most often absent at feeders when other species were feeding, grounds for future research would center on whether or not quail would be utilizing the feeders more in the event that some of the other species could be deterred.

\section{Evidence of predation at feeder sites}

Unnatural concentrations of quail at feeders may increase susceptibility of quail to predation and such concerns are often listed as a liability of supplemental feeding programs for quail (D. Rollins, Texas Agricultural Experiment Station, personal communication). Potential predators of quail recorded at feeders included bobcats, feral cats, coyotes, gray foxes (Urocyon cineroeargenteus), striped skunks, raccoons, opossums and roadrunners. In this study however, only 1 instance of predation on quail (a bobwhite at the Fisher County site) was recorded at or near feeders. However, 15 instances of predation of mourning doves were reported and occurred across all study sites. Special concerns relative to dove hunting

Doves (mostly mourning doves) were about 3 times more likely to visit a feeder than quail. These observations suggest that dove hunting in the presence of free-choice quail feeders may constitute baiting, i.e., a violation of state and federal regulations for migratory birds. 


\section{CONCLUSIONS AND MANAGEMENT IMPLICATIONS}

The reigning conundrum over the efficacy of supplemental feeding of quail remains the issue of what portion of the feed provided is actually consumed by quail as opposed to non-target species. The cost of supplemental feeding can be substantial; e.g., approximately $\$ 15$ per week per feeder in this study for feed costs alone. Expenses for labor and travel would further increase feeding costs, and feed loss to non-target species like raccoons would exacerbate both costs. Boyer (1989) reported that an additional quail in the bag could cost from $\$ 24$ to $\$ 60$ in successful feeding programs. Quail visitation was incidental in relation to visitation by non-target species (Fig. 19). Managers of supplemental feeding programs should monitor species visitation at feeders to estimate how much feed is being consumed by quail. Such reconnaissance may suggest management strategies to diminish the amount consumed by non-target species.

Doerr and Silvy (2002) opined that supplemental feeding will successfully improve survival and reproduction of bowhites only if food supply is the

principal factor limiting populations. Feeding cannot overcome deficiencies of habitat structure, excessive harvest or other limiting environmental factors. If habitat structure is inappropriate, then 


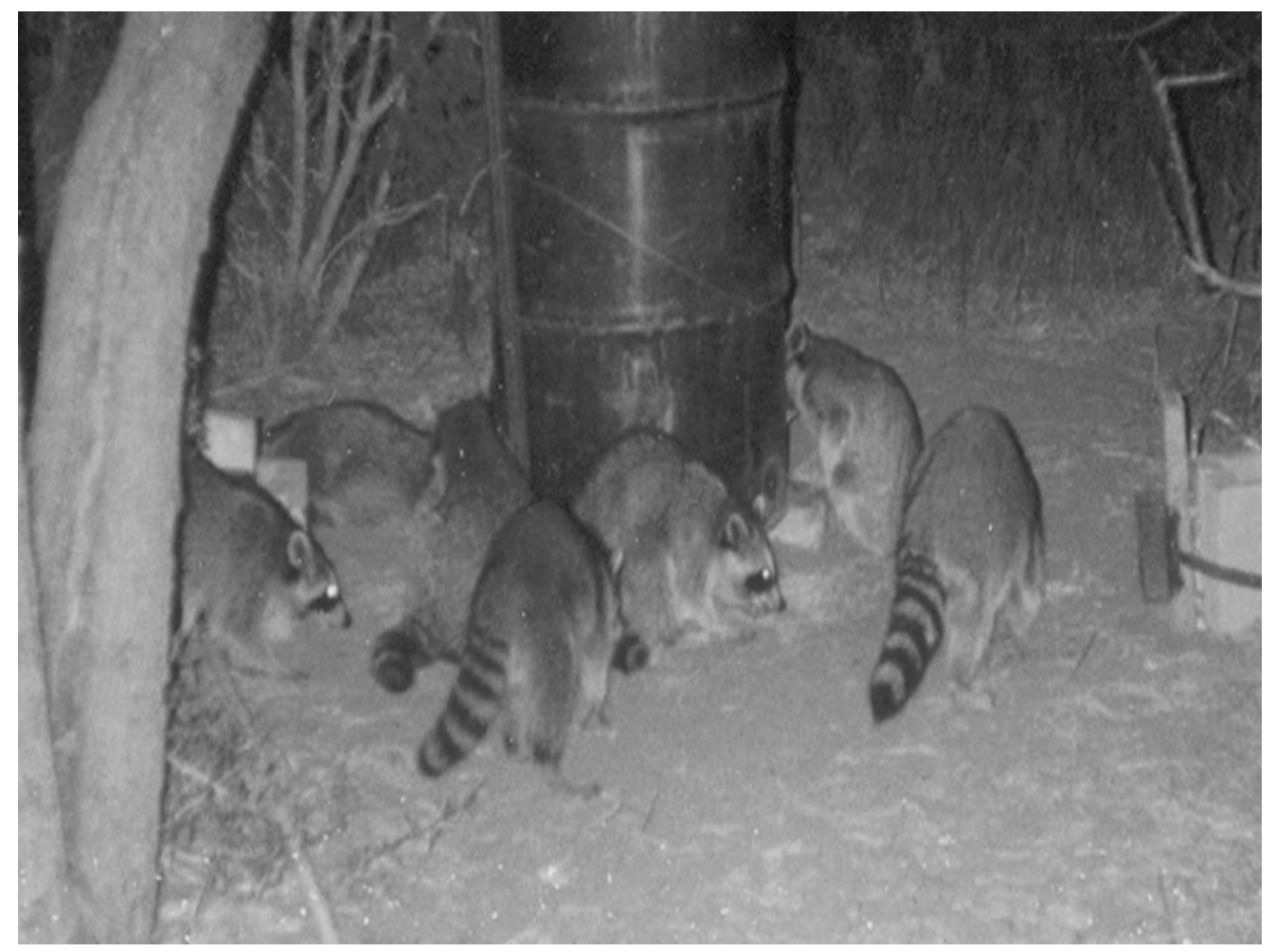

Figure 19. Raccoons were the most problematic non-target species encountered during a study of free-choice quail feeders in west Texas, fall 2002 - summer 2003. 
habitat improvement, rather than supplemental feeding, should be the priority of management plans. That said, feeding for quail seems to be mostly a biologically neutral practice. Concerns about feeders increasing predation have not been documented empirically. Another factor to consider when contemplating a supplemental feeding program is a possible indirect effect on nest survival. Cooper and Ginnett (2000) found decreased nest success of quail when deer feeders were in the vicinity of the nesting area.

Deer feeders are known to attract raccoons and other predators of ground nesting birds, which could prove detrimental to nearby quail populations. It is recommended that managers concerned with quail should avoid placing deer feeders in quail-nesting habitats or cease supplemental feeding during the nesting season (Cooper and Ginnett 2000).

Manufacturers of quail feeders frequently address the issue of non-target species in their advertisements and often tout the effectiveness of their respective "critter-proof" quail feeders. Strategies employed by manufacturers include sheltered entries to feeder holes allowing access by quail but not larger species and automatic timers on feeders that allow the user to set times for feed availability. However, this technology can cost between $\$ 300-\$ 400$ per feeder. As raccoons were the most problematic non-target species in my study, timed feeders could be effective at minimizing feed loss to raccoons, and hence justify their relatively high costs (relative to the free-choice feeders employed in this 
study). However, this method has not been tested and it is not known if raccoons in the areas would modify their feeding behavior to allow for visitation of feeders at dawn and dusk

Other possible innovations for minimizing feed loss to raccoons include spraying a taste aversive substance such as capsacin on feeder holes or strategic use of fencing to deter wild turkeys. Electric fencing placed around the perimeter of the quail feeder might be used to deter raccoons. Trapping and removing raccoons would likely be ineffective, as other raccoons will quickly move into the area (Lyons 2001). According to Wildlife Care of Ventura (http://www.wildlifecareofventura.org), there are several deterrents specifically geared for raccoons. Light- and audio-stimuli have been promoted to homeowners in an attempt to make their property less appealing to raccoons. However, I doubt such stimuli would be effective. During my observations of raccoon behavior in this study, I noticed that once raccoons assessed the flashing of cameras and noises made by surveillance equipment, they quickly habituated to the novel stimuli which had no subsequent effect on feeding activities.

Feeders do effectively concentrate quail and make their locations on the landscape more predictable for hunting purposes. While feed loss to some nontarget species (e.g., raccoons) may be ameliorated through technology or ingenuity, feed loss to other non-target species (e.g., nongame birds) should be dismissed as an overhead cost of feeding. 


\section{LITERATURE CITED}

ALEXY, K.J., J. W. GASSETT, D.D A. OSBORN, AND K.V. MILLER. 2001. Remote monitoring of scraping behaviors of a wild population of white-tailed deer. Wildlife Society Bulletin 29:873-878.

ALLEN, C.R., S. DEMARAIS AND R.L. LUTZ. 1995. Red imported fire ant impacts on northern bobwhite populations. Ecological Applications 5:632-638.

BOYER, D. A. 1989. Evaluation of feeders, waterers, and shelters for use in bobwhite management. Thesis. Texas A\&I University, Kingsville.

BRENNAN, L.A. 1991. How can we reverse the northern bobwhite population decline? Wildlife Society Bulletin 19:544-555.

BRENNAN, L.A. 2002. A decade of progress, a decade of frustration. National Quail Symposium 5: 230-232.

CAMPBELL, H. 1957. Relative value to quail and doves of water alone, as compared to water plus supplemental, artificially provided food. New Mexico PR Project Completion Report, Project No. W-70-R, 1-2-3. New Mexico Department of Game and Fish, Albuquerque, New Mexico.

COOPER, S.M. AND T.F. GINNETT. 2000. Potential effects of supplemental feeding of deer on nest predation. Wildlife Society Bulletin 28:660-666. 
COWARDIN, L.M. AND J.E. ASHE. 1965. An automatic camera device for measuring waterfowl use. Journal of Wildlife Management 29:636640.

DEMASO, S. J., D. E. TOWNSEND, II. S. A. COX, E. S. PARRY, R. L. LOCHMILLER, AND A. D. PEOPLES. 2002. The effects of quail feeders on northern bobwhite density in western Oklahoma. National Quail Symposium 5:241 - 244.

DILL, H.H.. 1939. Winter feeding and shelters for the California valley quail. Transactions of North American Wildlife and Natural Resources Conference 4:474- 477.

DOERR, T.B., AND N. J. SILVY. 2002. Effects of supplemental feeding on northern bobwhite populations in south Texas. National Quail Symposium 5:233 - 240 .

FIES, M. L. AND K. M. PUCKETT. 2000. Depredation patterns of northern bobwhite nest predators in Virginia. National Quail Symposium 4: 96-102.

FORESMAN, K.R. AND D. E. PEARSON. 1998. Comparison of proposed survey procedures for detection of forest carnivores. Journal of Wildlife Management. 62:1217-1226.

FRYE, O.E. 1954. Studies of automatic quail feeders in Florida. Transactions of the North American Wildlife Conference 19:298-315. 
GIULIANO, W.M., R.S. LUTZ AND R. PATINO. 1996. Reproductive responses of adult female northern bobwhite and scaled quail to nutritional stress. Journal of Wildlife Management. 60:302-309.

GUTHERY, F.S. 1986. Beef, brush and bobwhites: quail management in cattle country. Caesar Kleberg Wildlife Research Institute Press, Kingsville, Texas.

GUTHERY, F.S. 1997. A philosophy of habitat management for northern bobwhites. Journal of Wildlife Management. 61:291-301.

GUTHERY, F.S., T.L. HILLER, W.H. PUCKETT, R.A. BAKER, S.G. SMITH AND A.R. RYBAK. 2004. Effects of feeders on dispersion and mortality of bobwhites. Wildlife Society Bulletin 32: 1248-1254.

HAUGEN, A.O. 1957. Quail and quail feeders. Alabama Conservationist 29:4-9.

HERNANDEZ, F., D. ROLLINS AND CARROLL, AND R. CANTU. 1997. An evaluation of TrailMaster ${ }^{\mathrm{TM}}$ camera systems for identifying ground-nest predators. Wildlife Society Bulletin 25:848-853.

JONES, D. D., L. M. CONNER, R. J. WARREN, AND G. O. WARE. 2002. The effect of supplemental prey and prescribed fire on success of artificial nests. Journal of Wildlife Management 66:1112-1117.

KANE, A.H. 1988. Effects of management on bobwhite habitat and density in southern Texas. Thesis, Texas A\&M University, Kingsville. 
KEITT, B.S., B.R. TERSHY AND D.A. CROLL. 2004. Nocturnal behavior reduces predation pressure on black-vented shearwaters (Puffinus opisthomelas). Marine Ornithology 32: 173-178.

KOERTH, B.H. AND J.C. KROLL. 2000. Bait type and timing for deer counts using cameras triggered by infrared monitors. Wildlife Society Bulletin 28:630- 635 .

KOZICKY, E.L. 1996. Protein pellet feed delivery systems for white-tailed deer. Pages 101-107 in C.W. Ramsey (ed) Supplemental feeding for deer: beyond dogma symposium proceedings. Texas A\&M Research and Extension Center, Kerrville, Texas.

KROLL, J.C. AND B.H. KOERTH. 1996. Solving the mysteries of deer movement. Center for Applied Studies in Forestry. Stephen F. Austin State University. Nacogdoches, Texas.

KUCERA, T.E. AND R.H. BARRETT. 1995. The Trailmaster camera system for detecting wildlife. Wildlife Society Bulletin 23:110-113.

LANGDON, C.A. 2001. A comparison of white-tailed deer population estimation methods in west Virginia. Thesis. West Virginia University, Morgantown.

LARIVIERE, S. 1999. Reasons why predators cannot be inferred from nest remains. Condor 101:718-721.

LEHMANN, V.W. 1984. Bobwhites in the Rio Grande plain of Texas. Texas A\&M University Press, College Station. 
LYONS, E.K. 2001. Effects of short term predator control on nesting success and survival of northern bobwhites (Colinus virginianus). Thesis, Angelo State University, San Angelo, Texas.

MARTORELLO, D. A., T.H. EASON, AND M.R. PELTON. 2001. A sighting technique using cameras to estimate population size of black bears. Wildlife Society Bulletin 29: 560-567.

MOORE, D. L. 2004. The acute effects of aflatoxin on granivorous avian species. Thesis, Texas A\&M University, Kingsville

MORUZZI, T. L., T. K. FULLER, R. M. DEGRAAF, R. T. BROOKS, AND W. LI. 2002. Assessing remotely triggered cameras for surveying carnivore distribution. Wildlife Society Bulletin 30:380-386.

OBERHEU, D.G. AND C.B. DABBERT. 2001. Aflatoxin production in supplemental feeders provided for northern bobwhite in Texas and Oklahoma. Journal of Wildlife Diseases 37: 475-480

PALMER, D.A., 1987. Annual, seasonal and nightly variation in calling of boreal and northern saw-whet owls. Biology and Conservation of Northern Forest Owls: Symposium Proceedings. 162- 168.

PEOPLES, A.D. 1992. Production, utilization and nutritional value of supplemental feed to northern bobwhites in western Oklahoma. Thesis, Oklahoma State University, Stillwater. 
PEREZ, M., S.E. HENKE AND A.M. FEDYNICH. 2001. Detection of aflatoxin-contaminated grain by three granivorous bird species. Journal of Wildlife Diseases 37: 358-361.

PIETZ, P.J. AND D.A. GRANFORS. 2000. Identifying predators and fates of grassland passerine nests using miniature video cameras. Journal of Wildlife Management 64:71-87.

ROLLINS D. AND J.P. CARROLL. 2001. Effects of predation on northern bobwhite and scaled quail. Wildlife Society Bulletin. 29:39-51.

SAVIDGE, J.A. AND T.F. SEIBERT. 1988. An infrared trigger and camera to identify predators at artificial nests. Journal of Wildlife Management 52:291-294.

STALLER, E.L. 1995. Identifying predators and fates of northern bobwhite nests using miniature video cameras. Thesis, University of Georgia, Athens.

STEWART, R.G. 1985. Natural exposure of bobwhite quail to aflatoxin. Dissertation, University of Georgia, Athens.

SWANN, D.E., C.C. HASS, D.D. DALTON AND S.A. WOLF. 2004. Infrared-triggered cameras for detecting wildlife: an evaluation and review. Wildlife Society Bulletin 32:357-365. 
SWEITZER, R.A., D.VAN VUREN, I.A. GARDNER, W.M. BOYCE, AND J.D. WAITHMAN. 2000. Estimating sizes of wild pig populations in the north and central coast regions of California. Journal of Wildlife Management 64:531-543.

TAYLOR, B.D. 2002. Whole cottonseed: voluntary intake by deer and avoidance by non-target species. Thesis. Angelo State University, San Angelo, Texas.

TOWNSEND, D.E., II, R.L. LOCHMILLER, S.J. DEMASO, D.M. LESLIE, JR., A.D. PEOPLES, S.A. COX AND E.S. PARRY. 1999. Using supplemental food and its influence on survival of northern bobwhite (Colinus virginianus). Wildlife Society Bulletin 27:10741081.

UTSCHICK, H. 2003. Lunar influence on diurnal bird activities in a riverine landscape. Ornithological Review 42:17-40.

WEBB, W.M., AND F.S. GUTHERY. 1982. Response of bobwhite to habitat management in northwest Texas. Wildlife Society Bulletin 10:142-146.

WILKINS, N., A. HAYS, D. KUBENKA, D. STEINBACH, W.GRANT, E. GONZALES, M. KJELLAND AND J. SHACKELFORD. 2003. Texas rural lands: trends and conservation implications for the $21^{\text {st }}$ century. Texas Cooperative Extension Publication B-6134. College Station, Texas. 
WILSON, H.R., J.G. MANLEY, R.H. HARMS AND B.L. DAMRON. 1978. The response of bobwhite quail chicks to dietary ammonium and antibiotic-vitamin supplement when fed B1 aflatoxin. Poultry Science 57: 403-407.

WINKLER, W. G. AND D. B. ADAMS. 1968. An automatic movie camera for wildlife photography. Journal of Wildlife Management. 32:949-952.

WOLF, K. N., F. ELVINGER, AND J. L. PILCICKI. 2003. Infraredtriggered photography and tracking plates to monitor oral rabies vaccine bait contact by raccoons in culverts. Wildlife Society Bulletin. 31:387391.

YORK, E.C., T.L. MORUZZI, T.K. FULLER, J.F. ORGAN, R.M. SAUVAJOT, AND R.M. DEGRAAF. 2001. Description and evaluation of a remote camera and triggering system to monitor carnivores. Wildlife Society Bulletin. 29:1228-1237. 
VITA

Kelly Diane Henson was born on 28 October 1973 in Garland, Texas. She is the daughter of David F. and Linda Kingston.

After graduating from Central High School, San Angelo, Texas, in 1992, Kelly attended Angelo State University. She graduated with a Bachelor of Arts Degree in Psychology in 2000 and enrolled in graduate school at Texas A\&M University. Kelly received a Master of Science in Wildlife and Fisheries Sciences in May 2006.

Kelly Henson can be contacted at the Texas A\&M Research and Extension Center, 7887 US Highway 87 North, San Angelo, TX 76901, Phone 325-653-4576. 